\author{
UniVERSIDADE de SÃo PaUlo \\ Faculdade de Odontologia de Ribeirão Preto
}

FRANCINE LORENCETtI DA SILVA

Avaliação da Expressão Gênica de Células Da Polpa

Dentária Após Estimulação Com Microesferas Contendo

Mediadores LipÍdicos

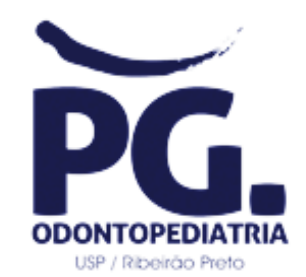

Ribeirão Preto

2015 
Francine LORENCETtI dA SiLVA

\section{Avaliação da Expressão Gênica de Células Da Polpa \\ Dentária Após Estimulação Com Microesferas Contendo}

\section{Mediadores LipÍdicos}

Dissertação apresentada à Faculdade de Odontologia de Ribeirão Preto da Universidade de São Paulo, para obtenção do Título de Mestre em Ciências.

Área de Concentração: Odontopediatria

Orientador: Dr. Francisco W. Garcia de Paula e Silva

Ribeirão Preto 


\section{AUTORIZAÇÃO PARA REPRODUÇÃO}

Autorizo para reprodução e divulgação total ou parcial deste trabalho por qualquer meio convencional ou eletrônico, para fins de estudo e pesquisa, desde que citada a fonte.

\section{FICHA CATALOGRÁFICA}

Lorencetti-Silva, Francine

Avaliação da expressão gênica de células da polpa dentária após estimulação com microesferas contendo mediadores lipídicos. Ribeirão Preto, 2015.

95p. : il. ; $30 \mathrm{~cm}$

Dissertação de Mestrado apresentada à Faculdade de Odontologia de Ribeirão Preto/USP - Área de Concentração: Odontopediatria.

Orientador: Paula-Silva, Francisco Wanderley Garcia de

1. Inflamação 2. Leucotrieno $B_{4}$ 3. Prostaglandina $E_{2} 4$. Complexo Dentino-Pulpar 
lorencetti-Silva, F. Avaliação da expressão gênica de Células da polpa DentÁRIA APÓS ESTIMULAÇÃo COM MICROESFERAS CONTENDO MEdiadores LIPÍDICOS

Dissertação apresentada à Faculdade de Odontologia de Ribeirão Preto da Universidade de São Paulo, para obtenção do Título de Mestre em Ciências

Área de Concentração: Odontopediatria

Data da defesa:

\section{Banca Examinadora}

Prof. Dr.

Instituição:

Julgamento: Assinatura:

Prof. Dr.

Instituição:

Julgamento: Assinatura:

Prof. Dr.

Instituição:

Julgamento: Assinatura: 



\section{Dados Curriculares}

\section{Francine Lorencetti da Silva}

Nascimento 20 de dezembro de 1990 - Jardinópolis/SP

Filiação Marcos Elísio da Silva

Carmem Sílvia Lorencetti da Silva

2009-2012 Curso de Graduação (Universidade de São Paulo)

Faculdade de Odontologia de Ribeirão Preto

Iniciação científica: Avaliação radiográfica digital das

estruturas periodontais, dentina e polpa dentária de crianças com bruxismo do sono.

Orientadora: Profa.Dra. Kranya Victoria Díaz-Serrano

2013-2014 Curso de Aperfeiçoamento

Atendimento Odontológicos a Pacientes

Especiais (Universidade de São Paulo)

Faculdade de Odontologia de Ribeirão Preto

2013-2015 Curso de Especialização em Odontopediatria Associação odontológica de Ribeirão Preto - AORP

2013-2015 Curso de Pós-Graduação em Odontopediatria, nível Mestrado (Universidade de São Paulo) Faculdade de Odontologia de Ribeirão Preto 

Trabalho realizado com apoio financeiro do Programa de Auxílio à Pesquisa Jovem Pesquisador (processo 2010/17611-4), concedido pela Fundação de Amparo à Pesquisa do Estado de São Paulo (FAPESP), e Bolsa de Mestrado concedida pela Coordenação de Aperfeiçoamento de Pessoal de Nível Superior (CAPES). 



\section{DEDICATÓRIA}

A Deus, pelo dom da vida. Por todas as vezes que me deu forças quando eu achei não mais as tinha, e pelas inúmeras vezes que não me deixou desistir. Por guiar meus passos e me dar sabedoria para solucionar os problemas. Por me fazer acreditar em mim mesma e por ter me dado a oportunidade de encontrar pessoas especiais, que me aconselham, me acompanham, e tornam meus dias únicos e felizes. A curiosidade que o Senhor despertou em mim me motiva a continuar incansavelmente na busca por respostas. Obrigada!

A meus pais, Carmem Sîlvia Lorencetti da Silva e Marcos Elísio da Silva, meus anjos da guarda. Sou a pessoa que sou, por vocês... pelas inúmeras vezes que me disseram sim, mas especialmente pelas vezes que me disseram não. Vocês me ensinaram que para conquistar seus objetivos, não vale a pena passar por cima de valores éticos e morais. Vocês me mostraram que conquistas são feitas a partir de muito trabalho, determinação e, principalmente, humildade. Humildade para saber seu limite e pedir ajuda, sem desistir jamais. Obrigada pelo amor incondicional diário e por todas as palavras de amor, carinho e pela compreensão. Obrigada por não me deixarem desistir de meus sonhos e por viverem comigo cada conquista. Amo vocês!

Aos meus avós, Francisco da Silva, Raul Lorencetti, Maria Biancullo da Silva e Maria Celina Magiollo Lorencetti. Com vocês aprendi que a vida deve ser contemplada sempre. Cada minuto vivido, cada conversa trocada, cada risada e até cada lágrima caída tem seu valor único, que jamais deve ser desperdiçado, pois na vida não vale a pena desperdiçar o tempo com preocupações, angústias e medos, mas com questionamentos, a busca por soluções e com pessoas. Sim, com pessoas que nos fazem mais felizes, que nos somam e que nos transformam no melhor que podemos ser. Com vocês aprendi que viver cabe em um abraço de carinho, que nunca deve ser deixado para depois. Amo vocês, meus maiores mestres! 



\section{AGRADECIMENTO ESPECIAL}

A meu orientador, Dr. Francisco Wanderley Garcia de Paula e Silva. Francisco, você me ensinou que ser mestre não consiste apenas em saber usar técnicas corretas, medidas milimetricamente exatas. Pude aprender que as soluções não estão no óbvio, mas em tudo aquilo que nos faz questionar, pois raciocinar faz parte da vida e nos faz descobrir coisas incríveis. Você me ensinou que nem sempre a hipótese e o resultado são sinônimos, afinal entre estes dois conceitos existe uma linha tênue e ao mesmo tempo infinita que torna a arte de pesquisar ainda mais fascinante e intrigante. Aprendi ainda a ser mais paciente, buscar soluções onde elas pareciam impossíveis. Muitas vezes você me deixou caminhando sozinha, e eu me perguntava por que. Compreendi que, na verdade, eu precisava me descobrir. Descobrir meu potencial e saber que poderia chegar bem mais longe do que eu imaginava. Obrigada por me fazer compreender que o Mestre requer disciplina.

Obrigada pela oportunidade de ter sido sua orientada! Levarei seu exemplo de pessoa e profissional para sempre comigo. 



\section{AGRADECIMENTOS}

À Faculdade de Odontologia de Ribeirão Preto da Universidade de São Paulo, na pessoa do atual diretor Prof. Dr. Valdemar Mallet da Rocha Barros e à Coordenação do Curso de Pós-Graduação em Odontopediatria da Faculdade de Odontologia de Ribeirão Preto da Universidade de São Paulo, na pessoa da Profa. Dra. Raquel Assed Bezerra Segato e da Vice- Coordenadora Profá. Dra. Léa Assed Bezerra da Silva.

Ao Prof. Dr. Paulo Nelson-Filho e à Profa. Dra. Alexandra Mussolino de Queiroz, exemplos de pessoa e profissional. Com vocês aprendi que ser Odontopediatra exige paciência, dedicação e muito conhecimento. A essência do verdadeiro Mestre não vem apenas do saber, mas do saber transmitir, do saber ensinar. Obrigada pelas inúmeras vezes que apontaram meus erros e por me mostrarem o que eu poderia melhorar. Espero um dia poder seguir seus passos...

\section{Às Profá. Dra. Kranya Victoria Díaz-Serrano, Profa. Dra. Aldevina Campos} Freitas e Profa. Dra. Maria Cristina Borsatto Muitas vezes me espelhei em vocês para saber como me portar durante o atendimento, ou durante uma aula, mas me espelho em vocês, principalmente sobre como me portar diante da vida. Professora Kranya, obrigada por ter me mostrado o quão fascinante é o mundo da pesquisa, da descoberta do novo. Tudo começou há muitos anos atrás, quando meu sonho ainda era modesto, e quando eu nem poderia imaginar o quanto de coisas maravilhosas eu iria encontrar. Professora Aldevina, a senhora me ensinou que para ser bom no que se faz é preciso repetir inúmeras vezes, pois só assim se alcança a perfeição. A senhora me ensinou que só é possivel saber se para isso buscar, indagar, e me mostrou, ainda, que ser firme é diferente de ser rude. Obrigada! Professora Maria Cristina, só posso lhe agradecer pela paciência que demonstrou comigo desde o início de minha caminhada. Com a senhora aprendi a olhar mais para mim... aprendi que o que vale mais a pena na vida é vive-la de forma plena, sem valorizar tanto o amanhã, mas vivenciar de maneira absoluta o agora, e me mostrou que para se alcançar o impossível, basta querer, pois o impossivel se torna possível quando o medo é vencido. Obrigada por me fazer acreditar em mim mesma e pelo carinho de sempre! 
Ao corpo docente do Departamento de Clínica Infantil da Faculdade de Odontologia de Ribeirão Preto da Universidade de São Paulo, Prof á. Drá. Léa Assed Bezerra da Silva, Profa. Dra. Aldevina Campos de Freitas, Prof. Dr. Paulo Nelson-Filho, Profa. Dra Alexandra Mussolino de Queiroz, Prof. Dr. Fabrício Kitazono de Carvalho, Profa. Dra Kranya Victória Díaz-Serrano, Profa. Dra. Maria Cristina Borsatto, Prof ${ }^{a}$. Dra . Raquel Assed Bezerra Segato, Profa. Dra. Andiara de Rossi Daldegan, Profa. Dra . Mírian Aiko Nakane Matsumoto, Profa. Dra. Maria Bernadete Sasso Stuani, Prof. Dr. José Tarcísio Lima Ferreira, Prof. Dr. Adilson Thomazinho, Prof. Dr. Fábio Lourenço Romano e Profa. Dra. Maria da Conceição Pereira Saraiva pela convivência agradável e por todo ensinamento a mim transmitido. Obrigada pelas inúmeras vezes que se disponibilizaram em me auxiliar de alguma forma.

Às Profa. Dra Lucia Helena Faciolli e Profa. Dra Fabiana Gai Frantz. Obrigada por abrirem as portas do Laboratório de Imunologia e Inflamação das Parasitoses (LIIP) e do Laboratório de Imunologia e Epigenética (LIME), e pela ajuda que sempre me ofereceram. Aprendi que jamais conquistamos algo sozinhos. Obrigada pela forma como me acolheram e me ajudaram. Conquistei, sem dúvida alguma, muito mais do que os resultados desta dissertação, pois ganhei amigos que levarei comigo por toda a vida.

A meu namorado, Bruno Campioni. Com você aprendi que caminhar junto é muito mais do que estar junto fisicamente. É compartilhar sonhos, medos, conquistas...é estar um com o outro independente do que aconteça. Com você aprendi a ser mais confiante, a enfrentar meus medos e fraquezas. Aprendi que pra vencer é preciso muitas vezes errar, tentar de novo, mas jamais desistir. Obrigada pelas vezes que me levantou, enxugou minhas lágrimas e me fez continuar na busca dos meus sonhos. Obrigada por, de fato, caminhar junto comigo. Obrigada pelas vezes que me ajudou, de todas as formas, para que esta dissertação se concretizasse. Que caminhemos sempre juntos. Te amo!

Às minhas querida amigas Mariana de Oliveira Daltoé e Juliana Arid. Sem dúvida alguma devo muito a vocês cada conquista, pois vocês sempre estiveram ao meu 
lado em todos os momentos. Quando tudo dava certo, vocês comemoravam comigo, e quando tudo dava errado sempre pude contar com um abraço de carinho e palavras de motivação. Obrigada pelos sorrisos trocados, pelos abraços de consolo e pela linda amizade que construímos juntas. Obrigada pelas vezes que me confortaram. Vocês sempre estarão no meu coração e tenho certeza que, para sempre, estaremos juntas.

Aos meus amigos: Daniele Lucca Longo, Fernanda Regina Ribeiro dos Santos, Igor Bassi Ferreira Petean, Mariana de Oliveira Daltoé e Laura Alves Bastos. Obrigada pela amizade, carinho e respeito que sempre tiveram comigo. Vocês tornaram meus dias mais divertidos, mais cheios de vida! Obrigada por compartilharem comigo seu conhecimento, sua dedicação, e por nunca me deixarem caminhar sozinha. Vejo em vocês o verdadeiro reflexo de lealdade e companheirismo. Obrigada por me fazerem rir por horas e por confortarem o meu coração. Estarei sempre ao lado de vocês...

À minha querida amiga Fernanda Regina Ribeiro dos Santos. Fer, me lembro quando tudo começou...eu assustada, cheia de dúvidas, e você toda feliz me ensinando a dar os primeiros passos. Tenho muito orgulho de ser sua amiga e por, juntas, termos concretizado muitos de nossos sonhos. Obrigada por sempre me deixar fazer parte de suas conquistas, e obrigada por você também fazer parte das minhas. Te adoro muito!

Aos amigos e amigas da Pós-Graduação Sofia Sampaio Meireles de Souza, Mariana de Oliveira Daltoé, Juliana Arid, Carolina Maschietto Pucinelli, Silvana Polizeli, Marilia Moreira, Rodrigo Alexandre Valério, Driely Barreiros, Patrícia Maria Monteiro, Sara Silva de Oliveira, Leonardo Gontijo Matos, Daniele Lucca Longo, Ana Carolina Fumes, Denise de Souza Matos, Karina Grecca Pieroni, Katharina Morant Holanda de Oliveira, Mariana Alencar Namezio, Priscilla Coutinho Romualdo, Danielly Cunha Araújo Ferreira, Daniela Barroso, Lídia Hidalgo, Talitha de Siqueira Mellara, Marina Moscardini Vilela, Paula Regina Ávila Silvano, Maria Gabriela Flores Bracho, Elaine Machado Pingueiro, Larissa Nogueira Soares Ribeiro, Mariele Andrade, Claudia Carpio, Laura Alves Bastos, Thaís Aparecida Xavier, Nicole Gonçalves Lima e Raquel Morelli pelos momentos compartilhados. Obrigada pela adorável convivência! 
Aos meus eternos e queridos amigos da Turma LXXXIV da Faculdade de Odontologia de Ribeirão Preto da Universidade de São Paulo. Foi com vocês que meu sonho começou a ser traçado. Cada conquista minha, sem dúvida alguma, tem um pouquinho de cada um de vocês. Obrigada, pois mesmo distantes, estaremos sempre juntos, família 84 !

À Alyne Fávero Galvão, Caroline Fontanari e Priscila Ap. Tartari Pereira. Por muitas vezes, vocês sentaram comigo, me auxiliaram com cálculos, fórmulas e afins...sem dúvida alguma não teria feito nada sem a ajuda e a paciência de vocês. Obrigada pelas inúmeras vezes que vocês deixaram um pouquinho as coisas de vocês para me ajudarem em tudo o que eu precisei. Com toda certeza, a amizade que construímos será para sempre. Obrigada, meninas!

À Nilza Letícia Magalhães, Marco Antônio dos Santos e Fătima Aparecida Jacinto Daniel. Por muitas vezes vocês pegaram na minha mão, me acompanharam e mostraram como realizar esta ou aquela técnica. Por vezes, vocês deixaram de lado seus afazeres para me ensinarem, e isto jamais vou esquecer. Obrigada pelas vezes que me auxiliaram, pelas vezes que me incentivaram, mas principalmente, obrigada pelos sorrisos que tiraram de mim, por me contagiarem com sua alegria e pelos inúmeros "bom dia" que me deram, pois fizeram uma enorme diferença na minha caminhada. Adoro vocês!

A Marilia Pacífico Lucisano e Carolina Paes Torres Mantovani. Obrigada pela amizade de vocês e por tudo que fizeram por mim. Obrigada pelas oportunidades, pelos ensinamentos, pelos conselhos e por sua amizade. Um dia espero poder compartilhar da sabedoria, paciência e dedicação de vocês. Muito sucesso sempre!

Aos amigos do LIIP e do LIME: Karina Furlani Zoccal, Mouzarllen Barros dos Reis, Morgana Kelly Borges Prado, Ana Carolina Pagliaroni, Verônica Brauer, Leonardo Judson Galvão de Lima, Fabiana Albani Zambuzi, Milena Sobral Espíndola, Priscila Mariane Cardoso Silva, Luana Soares, Gisele Faria, Carlos Artério Sorgi, Fabiana Rosseto de 
Morais, Nadiele Fagundes e José Carlos de Paula Júnior. Estar com vocês diariamente foi um imenso prazer. Obrigada pelas vezes que vocês me ouviram e me estenderam a mão. Agradeço a amizade de cada um de vocês... levarei para sempre comigo!

Ás amigas Sandra Palma, Amanda Goulart, Josiane Carvalho, Naira Anchieta, Malena Martinez e Gretel Rodriguez. Tenho por cada uma de vocês um carinho especial e eterno. Vocês foram uma grande surpresa que Deus me deu...ser amiga de vocês é um presente. Espero que por mais distante que estejamos, continuemos próximas. Vocês me fizeram aprender muito. Obrigada pela amizade, meninas!

Aos funcionários do Departamento de Clínica Infantil e da Clínica de Pacientes Especiais da Faculdade de Odontologia de Ribeirão Preto da Universidade de São Paulo, Filomena Lelli Placciti, Matheus Morelli Zanela, Micheli Cristina Leite Rovanholo, Rosemary Alves, Vera do Nascimento Scandelai, Benedita Viana Rodrigues, Renata Cristina Rosa e Fátima Aparecida Rizoli pelas inúmeras conversas trocadas e por tornar meus dias mais leves e felizes. Obrigada por cada conselho dado e pela adorável convivência. Jamais esquecerei tudo o que fizeram por mim. Adoro vocês!

Às funcionárias da Seção de Pós-Graduação da Faculdade de Odontologia de Ribeirão Preto da Universidade de São Paulo Isabel Cristina Galino Sola e Mary Possani pela disposição e atenção que sempre deram a mim.

À CAPES (Coordenação de Aperfeiçoamento de Pessoal de Nivel Superior) e à FAPESP (Fundação de Amparo à Pesquisa do Estado de São Paulo), pelo apoio financeiro concedido para o desenvolvimento desta pesquisa.

A todos que tornaram possivel a concretização desta dissertação. Obrigada 



\section{SUMÁRIO}

\section{RESUMO}

\section{ABSTRACT}

1. INTRODUÇÃO

2. PROPOSIÇÃO

3. MATERIAIS E MÉTODOS

4. RESULTADOS

5. DISCUSSÃO

6. CONCLUSÃO

REFERÊNCIAS $\quad 87$ 



\section{RESUMO}

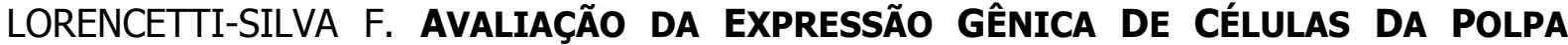 DENTÁRIA APÓS ESTIMULAÇÃO COM MICROESFERAS DE MEDIADORES LIPÍDICOS [DISERTAÇÃO]. RIBEIRÃO PRETO: UNIVERSIDADE DE SÃO PAULO, FACULDADE DE ODONTOLOGIA DE RIBEIRÃO PRETO, 2015. 95p.}

Durante a resposta inflamatória alguns mediadores lipídicos, destacando-se o Leucotrieno $\mathrm{B}_{4}$ $\left(L_{T B}\right)$ e a Prostaglandina $E_{2}\left(P_{G E}\right)$, são liberados no meio e desencadeiam uma série de eventos moleculares e celulares. Não diferentemente do que ocorre em outros tecidos, eventos inflamatórios na polpa também geram a produção destes mediadores lipídicos. Na polpa, entretanto, há presença de células-tronco que persistiram e permanecem indiferenciadas, mas com potencial capacidade de diferenciação em células odontoblast-like. O objetivo do presente estudo foi avaliar a expressão de genes codificadores da síntese e mineralização da matriz dentinária, bem como avaliar a viabilidade celular diante de células indiferenciadas da polpa de camundongos (linhagem OD-21) após estimulação com microesferas de $\mathrm{LTB}_{4}$ e $\mathrm{PGE}_{2}$. Foram preparadas microesferas contendo os mediadores lipídicos $(0,01 \mu \mathrm{M}$ e $0,1 \mu \mathrm{M})$ pelo método de simples emulsão óleo-água seguido do processo de evaporação do solvente. Células OD-21 foram mantidas em cultura com os diferentes tratamentos por um período de estimulação de 24 horas para realização de teste de viabilidade celular (Ensaio Colorimétrico MTT). A seguir foi realizada avaliação da expressão gênica relativa dos genes Ibsp, Bmp2, Runx2, $A / p l$, Msx1 e Bglap pelo método de transcrição reversa e reação em cadeia de polimerase em tempo real (qRT-PCR), utilizando o sistema $\operatorname{TaqMan}^{\circledR}$ após estimulação por períodos de 3, 6, 24, 48 e 72 horas. Foi observado aumento significativo no número de células viáveis após um período de 24 horas de estimulação com microesferas contendo $\mathrm{PGE}_{2}$ a $0,1 \mu \mathrm{M}$. A estimulação com microesferas, porém, não induziu a expressão de $A / p l$, Msx1 e Bglap, mas o fez para os genes Ibsp, Bmp2 e Runx2, em períodos mais curtos de estimulação. $A \mathrm{PGE}_{2}$ encapsulada em microesferas foi capaz de modificar o padrão de expressão gênica de Bmp2 e Runx2 em cultura de células OD-21, sendo que o $\mathrm{LTB}_{4}$ mostrou um papel inibidor da expressão gênica de Ibsp. Estes resultados indicam que estes mediadores podem ser importantes no processo de proliferação e diferenciação de células da polpa dental.

Palavras-chave: Inflamação, Leucotrieno $\mathrm{B}_{4}$, Prostaglandina $\mathrm{E}_{2}$, Complexo Dentino-Pulpar 



\begin{abstract}
lorencetTi-Silva F. evaluation Of Gene expression in Dental Pulp Cells AFTER ESTIMULATION WITH MICROESPHERES CONTAINING LIPID MEDIATORS [THESIS]. RIBEIRÃO PRETO: UNIVERSIDADE DE SÃO PAULO, FACULDADE DE ODONTOLOGIA DE RIBEIRÃO PRETO, 2015. 95p.

During the inflammatory response some lipid mediators, especially Leukotriene $\mathrm{B}_{4}\left(\mathrm{LTB}_{4}\right)$ and Prostaglandin $E_{2}\left(P E_{2}\right)$, are released into the environment and trigger a series of molecular and cellular events. Inflammatory events in the pulp also generate the production of these lipid mediators. However in the pulp there is the presence of stem cells that persisted and remain undifferentiated, but with ability to differentiate into odontoblast-like cells. The aim of to this study was to evaluate of gene expression encoding to the synthesis and mineralization of dentin matrix and to assess cell viability in undifferentiated cells of mice pulp (OD-21 strain) after stimulation with $\mathrm{PGE}_{2}$ and $\mathrm{LTB}_{4}$ microspheres. Microspheres containing lipid mediators were prepared $(0.01 \mu \mathrm{M}$ and $0.1 \mu \mathrm{M})$ using an oil-in water emulsion solvent extraction-evaporation process. OD-21 cells were maintained in culture with the different treatments during 24 hours for cell viability test (MTT colorimetric assay). After was made the evaluation of the relative gene expression of genes Ibsp, Bmp2, Runx2, Alpl, MsX1 and Bglap by reverse transcription method and real-time polymerase chain reaction (qRT-PCR), using the TaqMan ${ }^{\circledR}$ system after stimulation for 3, 6, 24, 48 and 72 hours. There was a significant increase in the number of viable cells following a 24 hours stimulation with microspheres containing $\mathrm{PGE}_{2} 0.1 \mathrm{uM}$. The microspheres stimulation did not induce the expression of $A / p l, M s x 1$ and Bglap, but did in genes Ibsp, Runx2 and Bmp2, in shorter periods of stimulation. $\mathrm{PGE}_{2}$ microespheres modified the pattern of Bmp2 and Runx2 gene expression in OD-21 cell culture whereas $\mathrm{LTB}_{4}$ revealed an inhibitory effect on Ibsp expression. These findings indicate that lipid mediators might be important for dental pulp cell proliferation and differentiation.
\end{abstract}

Keywords: Inflammation, Leukotriene $B_{4}$, Prostaglandin $E_{2}$, Dentin-Pulp Complex 



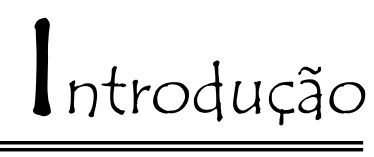





\section{İNTRODUção}

Os dentes decíduos iniciam sua formação entre a $3^{a}$ e $8^{a}$ semanas de vida intrauterina, cujo desenvolvimento envolve uma série de etapas complexas reguladas por interações entre o tecido epitelial e mesenquimal derivado da crista neural, sendo suas células constitutivas consequentemente derivadas do ectoderma (ameloblastos) e da crista neural (odontoblastos) (Thesleff, 2003; Larmas et al., 2013).

Para o desenvolvimento dentário propriamente dito, células ectomesenquimais derivadas do primeiro arco branquial e da crista neural migram e formam agregações celulares (da Cunha et al., 2013). O ectoderma fica mais espesso e gera brotos que invadem o mesênquima derivado da crista neural. O epitélio adjacente, então, passa a enviar sinais ao mesênquima que sofre condensação ao redor da banda epitelial, o qual sofre proliferação e cerca o mesênquima da papila dentária (Thesleff, 2003). As células epiteliais que sofrem o processo de diferenciação passam a secretar matriz de esmalte e são denominadas ameloblastos, enquanto que as células mesenquimais diferenciadas, agora denominadas odontoblastos, secretam dentina (da Cunha et al., 2013).

Após a completa diferenciação, os odontoblastos se caracterizam pela forma colunar alta, pela polarização nuclear e das organelas citoplasmáticas, e estão unidos uns aos outros por meio de complexos juncionais (Couve et al., 2013). Trata-se, portanto, de células pósmitóticas, organizadas sob a forma de uma camada celular periferal, presentes ao longo da interface dentina-polpa que apresentam processos celulares que se estendem no interior de estruturas tubulares circundadas por dentina, denominadas túbulos dentinários (Horst et al., 2009; Couve et al., 2013; Bleicher, 2014). Após o processo de diferenciação celular, os odontoblastos sintetizam matriz orgânica constituída por colágeno tipo I, e desempenham um importante papel na mineralização desta matriz por meio da secreção de proteoglicanas e proteínas não colágenas que participam da nucleação e controle do crescimento da fase mineral (Bleicher, 2014; Kuzinski et al., 2014). 
Portanto, durante a formação da dentina os odontoblastos secretam matriz rica em colágeno tipo I, a qual recebe a denominação de pré-dentina, constituindo assim a fase orgânica, que por sua vez é mineralizada por meio da incorporação de cristais de hidroxiapatita (HA) através do processo de biomineralização, o qual envolve mecanismos que controlam tanto os sítios quanto a taxa de deposição destes cristais (Qin et al., 2007; Kuzinski et al., 2014).

A fosfatase alcalina (ALPL) se mostra uma enzima indispensável para a mineralização da matriz secretada, pois fornece íons fosfato que geram a precipitação de minerais apatita, e hidrolisa o pirofosfato inorgânico, um éster fosfato inibidor da mineralização e presente no dente (Woltgens et al., 1995). Fosfatases alcalinas se apresentam em quatro isoformas (isozimas), incluindo a Fosfatase Alcalina Tissular NãoEspecífica (TNAP) (Hoylaerts et al., 2015). O processo de mineralização da matriz dentinária propriamente dita se inicia em vesículas de matriz derivadas da membrana plasmática compostas por proteínas e lipídios, o que permite o acúmulo de elevadas concentrações de íons cálcio $\left(\mathrm{Ca}^{2+}\right)$ e fosfato $\left(\mathrm{PO}_{4}{ }^{3-}\right)$, além da participação de Fosfatase Alcalina Tissular NãoEspecífica (TNAP). Esta enzima codificada pelo gene $A L P L$ leva à modificação da matriz extracelular e expressão de Fosfatase Orfan 1 (PHOSPHO 1), o fator iniciador da deposição de HA no interior da vesículas de matriz (Millán et al., 2013; Kuzynski et al., 2014).

Fibras colágenas também participam da enucleação e crescimento dos cristais de apatita (Chen et al., 2015), assim como proteínas não colágenas caracterizadas pela acidez devido às suas altas doses de ácidos aspártico e glutâmico, além de resíduos de serina fosforilada. Dentre elas se destacam a Proteína da Matriz Dentinária 1 (DMP-1) e a Sialofosfoproteína Dentinária (DSPP), ambas marcadores específicos para a dentina (George, 1994; Couve et al., 2013). A DMP-1 é expressa tanto nas células da polpa quanto em células odontoblásticas e é sugestivo que esta desempenhe um papel regulador importante na diferenciação de odontoblastos, além de participar na formação e 
mineralização da dentina tubular, se mostrando essencial tanto nos estágios mais precoces quanto mais avançados da odontogênese (Qin et al., 2007). A deposição mineral mediada pela DMP-1 tem início quando esta proteína se liga aos íons cálcio, pois o arranjo peptídico da enzima DMP-1 apresenta domínios correspondentes à estrutura dos cristais de HA, o que por sua vez reduz a energia de ativação e favorece a formação de núcleos cristalinos estruturalmente funcionais (He et al., 2003).

A DSPP, assim que secretada é rapidamente clivada em fragmentos $\mathrm{COOH}$-terminal e NH2-terminal. Este último é codificado pela porção $5^{\prime}$ do gene $D s p p$, resultando em uma forma proteica denominada Sialoproteína Dentinária (DSP) além de proteoglicanos, enquanto que a porção 3' é responsável pela codificação da porção NH2-terminal, a qual gera a Fosfoproteína Dentinária (DPP), sendo estas duas as proteínas não-colágenas mais encontradas na matriz dentinária (von Marschal e Fisher, 2010; Tsuchiya et al., 2011; Zhu et al., 2012).

A DSP é membro de uma família de proteínas denominadas SIBLINGs, acrônimo de Small Integrin-Binding Ligand N-linked Glycoproteins, que inclui ainda a Sialoproteína Óssea (BSP ou IBSP), Proteína da Matriz Dentinária-1 (DMP-1), Osteopontina (OPN), Fosfoglicoproteína de Matriz Extracelular (MEPE) e DSPP (Suzuki et al., 2009; Suzuki et al., 2012).

A DPP, por sua vez, contém grande quantidade de ácido aspártico e fosfoserinas, o que permite caracterizá-la como uma molécula polianiônica. A carga negativa distribuída ao longo desta proteína aumenta sua afinidade a íons cálcio e os expõem, desta maneira, às fibras colágenas presentes na frente de mineralização, permitindo o crescimento dos cristais de HA, o que lhe confere importância durante a fase de maturação da dentina mineralizada (Prasad et al., 2010; Suzuki et al., 2012).

O aumento na expressão do gene Dspp ocorre através de vias de sinalização cuja participação envolve a chamada Proteína Óssea Morfogenética-2 (BMP-2) e envolve ainda, 
dentre outros fatores, o Fator Transcricional 2 relacionado ao Runt (Runx2) (Staines et al., 2012).

As Proteínas Ósseas Morfogenéticas (BMPs) são moléculas de sinalização que fazem parte da superfamília do Fator de Crescimento Transformador $\beta$ (TGF- $\beta$ ) (Yamashiro et al., 2003). Além de aumentar a expressão do gene Dspp, a BMP-2 também desempenha um papel muito importante na regulação do processo de diferenciação de células da polpa dentária em odontoblastos, sendo que os mesmos são capazes tanto de produzir quanto clivar esta proteína (Yang et al., 2015).

O Runx2, por sua vez, é um fator de transcrição expresso na papila e saco dental, e está envolvido na diferenciação de odontoblastos e osteoblastos. Este fator transcricional tem a capacidade de aumentar a expressão de DSPP em odontoblastos imaturos, diferentemente do que ocorre nos casos de células completamente diferenciadas, o que revela que o efeito do Runx2 sofre influência do estado de diferenciação da célula odontoblástica (Camilleri e McDonald, 2006). Durante o desenvolvimento dentário, o Runx2 é expresso no mesênquima dental até à fase de capuz e, em seguida, tem sua expressão cessada na papila dental durante a fase de diferenciação dos odontoblastos, sugerindo que este gene apresenta importância na morfogênese dentária (Kim et al., 2015).

O processo de diferenciação terminal de células odontogênicas é resultante de interações moleculares que ocorrem entre o epitélio dental e as células ectomesenquimais, e envolvem além de BMPs, fatores de crescimento de fibroblastos (FGF) e fatores transcricionais como o $M s x$, os quais auxiliam as interações epitélio-mesenquimais cruciais para o início do desenvolvimento dentário (Lézot et al., 2000). O gene Msx corresponde a um membro da família dos genes homeobox expressos durante os estágios inicias de formação da região de cabeça, inclusive nas áreas de condensação do tecido ectomesenquimal do germe dentário (Cobourne et al., 2007). O fator transcricional MSX1 gera a proliferação de células mesenquimais e impede a diferenciação de odontoblastos na 
fase de capuz por meio da inibição da expressão de BMPs, incluindo a BMP-2 (Feng et al., 2013)

Uma proteína não-colágena presente na matriz dentinária secretada por odontoblastos é a Sialoproteína Óssea (IBSP) (Chen et al., 1998). Trata-se de uma glicoproteína ácida expressa por osteoblastos, odontoblastos e cementoblastos durante as fases inicias da mineralização, e tem a capacidade de se ligar à HA por meio de ligações ácidas sequenciais poliglutamínicas (Takai et al., 2014). A IBSP está presente nas vesículas de matriz e constitui uma das proteínas iniciadoras da deposição de cristais de HA. Este processo é possível graças à ação sinérgica com a enzima ALPL, pois na presença de IBSP, altos níveis desta enzima são capazes de induzir o início da deposição mineral (Staines et al., 2012).

A Osteocalcina (BGLAP) se revela como a principal proteína não colágena produzida por odontoblastos e osteoclastos, cujo papel é regular a organização da matriz extracelular através da interação com a HA, matriz proteica e receptores de superfície (Lombardi et al., 2015). Assim sendo, os odontoblastos secretam proteínas específicas da matriz dentinária, como a DSP e DPP derivadas da DSPP. Contudo, a dentina também apresenta em sua composição proteínas colágenas, IBSP, DMP-1, BGLAP e ALPL que, por conseguinte podem compartilhar vias regulatórias comuns, como por meio de fatores transcricionais, como RUNX-2 e MSX-1 (Papagerakis et al., 2002; Yang et al., 2014).

No entanto, além do importante papel dos odontoblastos no processo de síntese da matriz dentinária, como descrito anteriormente, estas células também são estruturas sensoriais importantes do órgão pulpar, pois apresentam a capacidade de detectar a invasão bacteriana durante o desenvolvimento da cárie dentária e, sequencialmente, iniciar a resposta imune na polpa (Bleicher, 2014).

Os processos infecciosos no tecido pulpar geram a ativação da resposta imune inata mediada por sinalização tanto celular quanto molecular. Os odontoblastos representam a 
primeira linha de defesa contra a invasão bacteriana neste ambiente (Farges et al., 2009; Cooper et al., 2014).

As células do sistema imune inato possuem receptores que reconhecem padrões moleculares associados ao patógeno (PAMPs), o que inclui os componentes bacterianos, como o lipopolissacarídeo (LPS) e o ácido lipoteicóico (LTA) (Pääkkönen et al., 2014). Através destes receptores de reconhecimento padrão (PRRs), os odontoblastos são capazes de responder à invasão de patógenos invasores, destacando-se os receptores do tipo Tolllike (TLR), mais especificamente os receptores TLR2 e TLR4, e Nucleotídeos Ricos em Leucina (NLRs), sendo os de maior destaque os receptores NOD2, capazes de reconhecer peptideglicanos presentes em bactérias Gram-positivas e Gram-negativas e, assim, ativarem as vias de sinalização MAPK e NF-kB, de modo a produzir citocinas pró-inflamatórias (Staquet et al., 2011). A interação do TLR-2 com o LTA, uma estrutura presente na parede celular de bactérias Gram-positiva e Gram-negativas, promove a translocação nuclear do fator de transcrição NF-kB, e gera a produção de quimiocinas, incluindo CCL2, CXCL1, CXCL2, CXCL8 e CXCL10, e recruta células dendríticas imaturas (Durand et al., 2006; Farges et al., 2009; Keller et al., 2010), além de reduzir a expressão de colágeno tipo 1 e DSPP, componentes da matriz dentinária (Durand et al., 2006). O receptor TLR4 reconhece o LPS presente em bactérias Gram-negativas e, consequentemente, aumenta a expressão de importantes citocinas pró-inflamatórias como IL-1ß, TNF-a e IL-8 (Veerayutthwilai et al., 2007). Além disso, receptores TLR4 podem desempenhar um papel crucial na resposta imune através da ativação e regulação dos processos de proliferação e migração de célulastronco da polpa (Liu et al., 2014).

O processo inflamatório gerado diante de estímulos nocivos deve ser entendido como um evento natural da resposta imune, resultando no recrutamento de células hematopoiéticas, as quais atravessam a barreira endotelial e atingem o local afetado pela injúria com o intuito de eliminar o dano e propiciar um ambiente adequado para o 
restabelecimento da homeostase (Farges, 2013). Assim é necessária a ativação dos PRRs, a liberação de mediadores, como o Leucotrieno $B_{4}\left(L_{T B}\right)$, principal mediador no recrutamento de polimorfonucleares (PMNs), e Prostaglandinas (PGs), como a Prostaglandina $E_{2}\left(P_{2}\right)$ (Crean and Godson, 2015).

PGs e LTs são moléculas bioativas derivadas da oxigenação do ácido araquidônico (AA) (Figura 1), um ácido graxo poli-insaturado derivado de fosfolipídios da membrana celular, por ação da enzima Fosfolipase $A 2\left(P L A_{2}\right)$, um grupo de proteínas que têm a capacidade de hidrolisar o ácido graxo na posição sn-2 de glicerofosfolípideos, especialmente o grupo PLA $\mathrm{P}_{2}$ IV $(\mathrm{CPLA})_{2}$, em decorrência de uma gama variável de estímulos celulares (Uozumi et al., 1997; Haeggström et al., 2010; Guijas et al., 2014). Por se tratarem de moléculas geradas a partir da oxidação do carbono 20 do ácido graxo poli-insaturado são denominados eicosanóides (do grego eikosi= vinte) (Harizi et al., 2008; Haeggström et al., 2010; Hammond and O'Donnel, 2012).

O AA livre pode ser metabolizado por meio das vias Cicloxigenase-1 (COX-1) e Cicloxigenase-2 (COX-2) e gerar Prostaglandinas (PGs) ou Tromboxanos (TX), ou pode ser oxidado ao longo da via Lipoxigenase (LO), que inclui a enzima 5- Lipoxigenase (5-LO), para produzir diferentes classes de LTs e Lipoxinas (Haeggström et al., 2010) (Figura 1).

Uma das vias de metabolismo do AA é a via 5-LO. Na presença de FLAP, uma proteína nuclear associada à membrana, a enzima 5-LO é ativada e oxida o AA, convertendo-o em ácido 5S- hidroxiperoeicosatetraenóico (5S-HpETE), o qual é ainda reduzido pela enzima peroxidase a ácido 5S- hidroxieicositetraenóico (5S-HETE) ou é convertido em $\mathrm{LTA}_{4}$, que por ação da $\mathrm{LTA}_{4}$ hidrolase, resulta em LTB (Powell e Rokach, 2015). Estes mediadores estão envolvidos na quimiotaxia de neutrófilos, células dendríticas e células $\mathrm{T}$, aumentam a permeabilidade vascular e atuam diretamente sobre células apresentadoras de antígenos (Rådmark et al., 2015). A quimiotaxia é correlacionada à 
ativação do receptor $\mathrm{BLT}_{1}$, além do receptor $\mathrm{BLT}_{2}$, sendo que este último revela baixa afinidade para $\mathrm{LTB}_{4}$ (Bäck et al., 2014).

As PGs, por sua vez, são produzidas por uma sequência de eventos que envolvem a ação das enzima COX-1 e COX-2 e têm sua base estrutural constituída pelo ácido prostanoico, o qual é composto por um anel de ciclopentano e duas cadeias de carbono, sendo conhecidas como prostanoides (Kawahara et al., 2015).

É importante salientar que a enzima COX-2 tem sua expressão induzida por uma gama de estímulos relacionados à resposta inflamatória, como fatores de crescimento e citocinas, e por isso é considerada a isoforma induzível da COX. Esta enzima é responsável pela síntese de PGs envolvidas na resposta inflamatória, embora sejam expressas em órgãos como o cérebro e os rins em condições fisiológicas. As PGs derivadas da COX-1 estão envolvidas na manutenção de funções biológicas (Clària, 2003). A enzima COX-2 metaboliza o $\mathrm{AA}$ e o converte na isoforma intermediária da $\mathrm{PGE}_{2}$ : a $\mathrm{PGH}_{2}$, a qual é convertida em $\mathrm{PGE}_{2}$ por meio das Prostaglandinas E sintases microssomais 1 e 2 (mPGE-1 e mPGE-2), sendo que este mediador, então, atua em 4 diferentes tipos de receptores de membrana (EP1, EP2, EP3 e EP4) acoplados à proteínas $G\left(G_{a s}, G_{i}\right.$ e $\left.G_{q}\right)$ e, a depender do tipo de receptor estimulado, diferentes vias celulares são ativadas (Legler et al., 2010) 


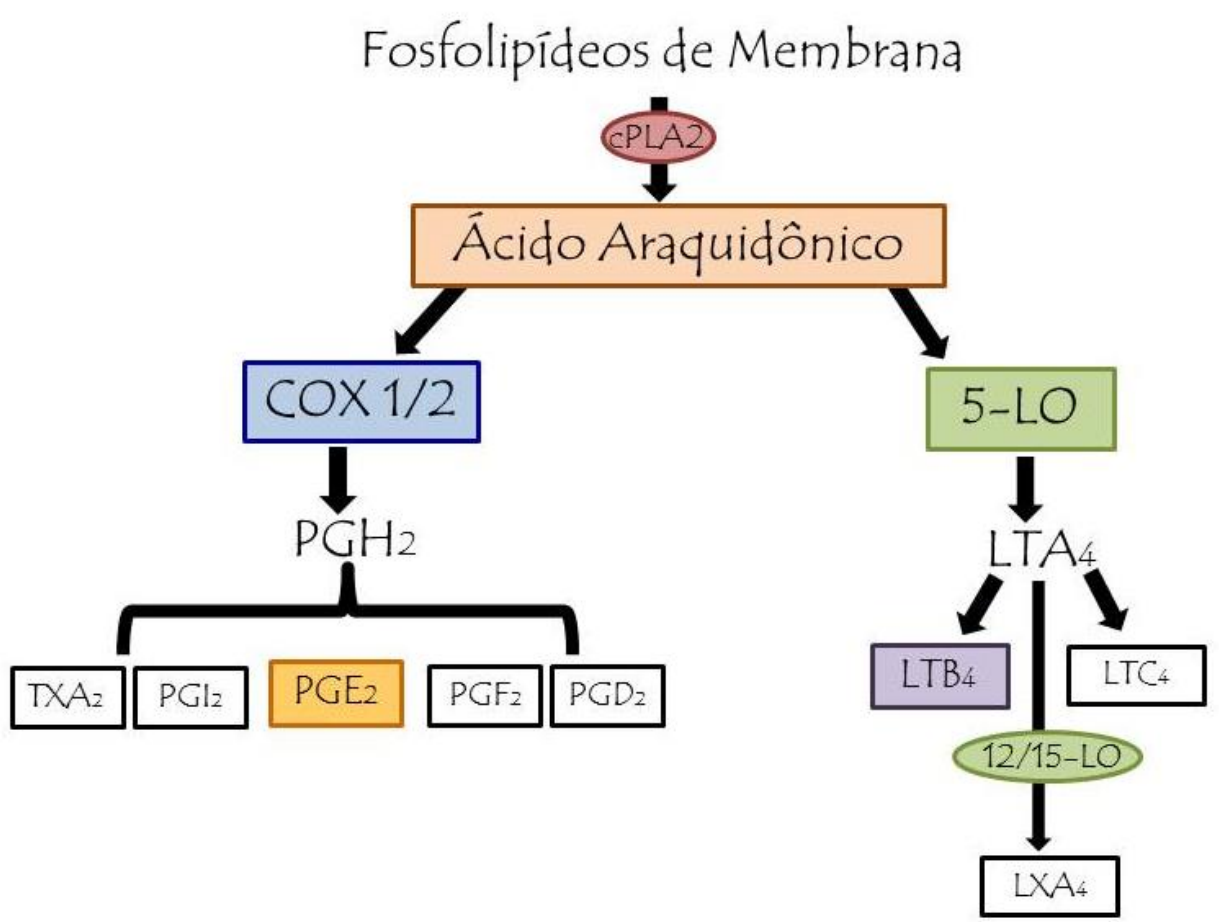

Figura 1. Representação esquemática do metabolismo do Ácido Araquidônico (adaptado de Haeggtröm et al., 2010).

Assim, a indução do processo inflamatório gera liberação de PGs, de modo preferencial $\mathrm{PGE}_{2}$ (Rodríguez et al., 2014), a qual se correlaciona ao aumento do fluxo sanguíneo local, aumento da permeabilidade vascular (quando associada a outros fatores solúveis, como os leucotrienos) e à sensibilização de fibras nervosas aferentes, gerando hiperalgesia por atuar em neurônios sensoriais periféricos e em sítios da medula espinhal e cérebro, sem contar que estes mediadores contribuem para a amplificação do padrão de resposta inflamatória, de modo a promover tanto o aumento quanto a prolongação dos efeitos e sinais produzidos por agentes pró-inflamatórios (Clària, 2003).

Sabe-se que, experimentalmente, a presença de LPS gera na polpa aumento no metabolismo do $A A$, resultando em maior expressão gênica e proteica de COX-2 e produção aumentada de $\mathrm{PGE}_{2}$ no meio com inflamação, estando esta envolvida no aumento de permeabilidade vascular da polpa (Okiji et al., 1987; Okiji et al., 1992 Santos, 2015). A produção de $\mathrm{LTB}_{4}$ se mostrou quase que paralela à infiltração de neutrófilos, o que revela 
envolvimento deste mediador na infiltração destas células em inflamação pulpar experimental (Okiji et al., 1992).

É bem estabelecido que polpa e dentina constituem uma só unidade, capaz de responder frente a estímulos externos, o que torna o complexo dentino-pulpar uma importante barreira estratégica e dinâmica às várias injúrias sofridas pelos dentes, sendo a cárie a causa mais comum de lesão a este complexo que resulta em alterações patológicas pulpares (Chogle et al., 2012).

Diante de agressões, os odontoblastos passam a produzir matriz dentinária próxima aos locais injuriados na tentativa de proteger o tecido pulpar da infecção microbiana (Charadram et al., 2013). A capacidade de resposta do complexo dentino-pulpar é possível graças à estimulação dos odontoblastos, os quais passam a sintetizar e secretar matriz dentinária reacional, matriz dentinária esta secretada por odontoblastos primários que sobreviveram à injúria tecidual sofrida via moléculas de sinalização semelhantes àquelas envolvidas na fase de dentinogênese (Téclès et al., 2005; Chogle et al., 2012). Esse processo de reparo ocorre diante do adequado suprimento sanguíneo, ausência de infecção (Smith e Lesot, 2001), e participação de citocinas pró-inflamatórias, fatores de crescimento (TGF- $\beta$ e BMPs), componentes da matriz extracelular e outras moléculas biologicamente ativas (Bleicher, 2014).

Por outro lado, em quadros pulpares inflamatórios intensos, a deposição de dentina reacional pelos odontoblastos pode ser cessada (Cooper et al., 2010; Bleicher, 2014), e o reparo dentinário pode ser realizado a partir de células-tronco presentes na polpa dental. Por meio da modificação do ambiente local, estas células têm seu comportamento e potencial de diferenciação afetados, pois diante da morte de odontoblastos primários, são capazes de sofrer diferenciação em células denominadas odontoblast-like, as quais passam a secretar matriz dentinária e depositá-la sob a forma de dentina reparadora (Teclès et al., 2005; Yalvac et al., 2010; Chogle et al., 2012; Chmilewiky et al., 2014). Deve-se destacar que as 
células-tronco mesenquimais são estruturas potencialmente imunorregulatórias, dotadas de função anti-infamatória, com capacidade de autorrenovação e diferenciação multilinhagem, e capazes de produzir estruturas similares às originais na polpa dental (Li et al., 2014).

Desta forma, o tecido pulpar se revela um ambiente com ampla capacidade de reparo, especialmente por apresentar células progenitoras e vias de sinalização de reparo induzidas pela dissolução da dentina cariada, o que gera a secreção de mediadores que propiciam a secreção de dentina reparadora, angiogênese e inervação (Chmilewsky et al., 2014).

Diante do exposto, os odontoblastos se mostram células de fundamental importância para iniciação e amplificação dos eventos da resposta imune inata na busca de proteção do órgão pulpar diante da presença de patógenos (Bleicher et al., 2014), assim como células indiferenciadas presentes na polpa e precursoras de odontoblastos, ambas sendo capazes de responder à injúrias por meio da modulação da resposta imune (Li et al., 2014). Além disso, mediadores lipídicos pró-inflamatórios como $\mathrm{PGE}_{2}$ e $\mathrm{LTB}_{4}$ estão envolvidos no padrão de resposta inflamatória, sendo seus mecanismos de ação bem conhecidos e amplamente descritos na literatura (Funk, 2001). Porém, não existem estudos que investigaram o papel dos mediadores lipídicos no comportamento celular pulpar, mimetizando a resposta destas células a um processo inflamatório.

Assim, a investigação da influência dos mediadores lipídicos no comportamento celular na polpa dental, de modo especial através da avaliação da expressão de genes codificadores de proteínas importantes para síntese e deposição de matriz dentinária em células indiferenciadas, se fez necessária. 

Proposição 



\section{Proposição}

\section{Objetivo Geral:}

O objetivo geral do presente estudo foi avaliar a expressão de importantes genes codificadores e necessários para a síntese e deposição de matriz dentinária utilizando, para tanto, células indiferenciadas da polpa de camundongos (Linhagem OD-21) estimuladas com mediadores lipídicos ( $\mathrm{LTB}_{4}$ e $\left.\mathrm{PGE}_{2}\right)$ encapsulados em microesferas e em diferentes molaridades.

\section{Objetivos Específicos:}

$\checkmark \quad$ Avaliar a viabilidade e proliferação celular após a estimulação com mediadores lipídicos encapsulados sob a forma de microesferas pelo ensaio MTT.

$\checkmark$ Avaliar a expressão de genes codificadores de fatores transcricionais e de importantes proteínas indutoras da síntese e deposição da matriz dentinária em cultura de células de linhagem utilizando a técnica de RT-PCR por meio da análise do RNA mensageiro. 

Material e Métodos 



\section{MAterial e MÉtodos}

\section{Mediadores Lipídicos}

Os mediadores lipídicos utilizados para o estímulo celular foram o Leucotrieno $\mathrm{B}_{4}$ $\left(\mathrm{LTB}_{4}\right)$ e a Prostaglandina $\mathrm{E}_{2}\left(\mathrm{PGE}_{2}\right)$, sob a forma de microesferas nas molaridades de 0,01 $\mu \mathrm{M}$ e $0,1 \mu \mathrm{M}$.

Para obtenção das microesferas foi utilizado o método de simples emulsão óleoágua seguido do processo de evaporação do solvente. Foram utilizados os mediadores LTB $_{4}$ e $\mathrm{PGE}_{2}$ a partir de uma solução estoque (5mg; Cayman Chemical Company, Michigan, USA), nas concentrações de $3 \times 10^{-5} \mathrm{M}$ e $7 \times 10^{-3} \mathrm{M}$, respectivamente, dissolvidos em etanol absoluto. O ácido polilático-coglicólico (PLGA 50:50) (Boehringer Ingelheim, Germany) foi o polímero utilizado para proteger o mediador lipídico da degradação. Assim, $30 \mathrm{mg}$ de PLGA foram dissolvidos em $9 \mathrm{~mL}$ de Diclorometano P.A. A.C.S. $\left(\right.$ Synth $^{\circledR}{ }^{\circledR}$, Diadema, São Paulo, Brasil), um hidrocarboneto clorado que funciona como solvente. Os mediadores foram adicionados ao PLGA e ao solvente, constituindo dessa forma, a emulsão.

Cerca de $40 \mathrm{~mL}$ de álcool polivinílico a 3\% (PVA a 3\%) (Sigma-Aldrich CO., St. Louis, MO, USA) foram acondicionados em um becker e as hastes do agitador RW-20 (Ika ${ }^{\circledR}$ Werke GmbH \& CO. KG, Staufen, Germany) foram posicionadas de maneira tal que não encostassem na parede inferior do Becker. O aparelho foi então ligado até atingir velocidade de $600 \mathrm{rpm}$.

Com auxílio de um bastão de vidro, a emulsão foi adicionada ao PVA (fase aquosa externa) e permaneceu sob constante agitação por um período de 4 horas, de modo a promover a evaporação do solvente e constituir a emulsão final óleo-água. Após a agitação, a emulsão final foi cuidadosamente transferida para tubos de $50 \mathrm{~mL}$ de fundo redondo autoclavados e previamente tratados com solução de $\mathrm{NaOH} 1 \mathrm{M}$, por uma hora, para evitar a contaminação por LPS. Sequencialmente, os tubos contendo a emulsão foram centrifugados a 16.000 rpm por cinco minutos, com o intuito de lavar o PVA e eliminar qualquer resquício 
de substância não encapsulada (Centrifuge 5810R-Eppendorf, Hamburg, Germany). Este passo técnico foi repetido três vezes, sendo que o sobrenadante foi descartado após cada lavagem seguido da adição de $25 \mathrm{~mL}$ de água ultrapura (Milli- ${ }^{\circledR}$, Merck Millipore, Darmstadt, Germany) para ressuspender o precipitado no agitador de tubos.

Ao final das lavagens, $500 \mu \mathrm{L}$ de água ultrapura foram adicionados em cada tubo, para ressuspensão do precipitado e transferência para frascos autoclavados. Cada frasco foi vedado com parafilm e mantido sob refrigeração a $-80^{\circ} \mathrm{C}$ até passar pelo processo de liofilização. O processo de liofilização foi realizado por 30 minutos, a vácuo em liofilizador Liotop (Liobras, São Carlos, São Paulo, Brasil), de modo a gerar a sublimação da água presente nas amostras. Após a etapa de liofilização as amostras foram mantidas a $-20^{\circ} \mathrm{C} \mathrm{e}$ protegidas da luz até sua utilização na etapa de experimentos.

Microesferas vazias foram usadas como controle, e também foram obtidas pelo método descrito anteriormente.

\section{Grupos Experimentais}

A detecção da expressão de genes que transcrevem proteínas indutoras da mineralização da matriz dentinária foi avaliada após a exposição das células da linhagem OD21 aos mediadores lipídicos em diferentes períodos experimentais (3, 6, 24, 48 e 72 horas).

Tabela 1. Grupos experimentais e tratamentos utilizados em experimentos

\begin{tabular}{ll} 
Grupos & Material \\
L001 & Microesferas de $\mathrm{LTB}_{4}$ com molaridade de $0,01 \mu \mathrm{M}$ \\
L01 & Microesferas de $\mathrm{LTB}_{4}$ com molaridade de $0,1 \mu \mathrm{M}$ \\
P001 & Microesferas de $\mathrm{PGE}_{2}$ com molaridade de $0,01 \mu \mathrm{M}$ \\
P01 & Microesferas de $\mathrm{PGE}_{2}$ com molaridade de $0,1 \mu \mathrm{M}$ \\
\hline
\end{tabular}


Como controle negativo, as células foram expostas a microesferas vazias com relação massa/volume semelhante à mesma relação obtida com microesferas com molaridades de 0,01 $\mu \mathrm{M}$ e 0,1 $\mu \mathrm{M}$, além do uso de Dulbecco's Modified Eagle Medium incompleto (DMEM-i).

\section{Preparo das Amostras}

O presente estudo foi realizado de acordo com o protocolo descrito anteriormente por Nicolete et al., 2007 e Nicolete et al., 2008a no tocante à descrição e eficiência de encapsulação dos mediadores lipídicos utilizados. Estes estudos foram realizados no Laboratório da Inflamação e Imunologia das Parasitoses (LIIP), da Faculdade de Ciências Farmacêuticas de Ribeirão Preto (FCFRP) da Universidade de São Paulo (USP), sob supervisão da Profa. Dra. Lúcia Helena Faccioli.

Tomando como base o estudo de Nicolete et al. (2008a), sabe-se que a eficiência de encapsulação da $\mathrm{PGE}_{2}$ é de $75.7 \%$, o que representa uma concentração de $12,8 \times 10^{-3}$ $\mu \mathrm{g} / \mathrm{mL}$ em $2 \mathrm{mg}$ de massa total da microesfera solubilizadas em $1 \mathrm{~mL}$ de acetonitrila/etanol. Esse valor representa uma molaridade de $3,8 \times 10^{-8} \mathrm{M}$. Portanto, para obtenção de $0,1 \mu \mathrm{M}$ de microesferas de $\mathrm{PGE}_{2}, 0,033 \mathrm{~g}$ de microesferas foram solubilizadas em um volume de $6 \mathrm{~mL}$ de meio DMEM-i. A partir desta solução mais concentrada diluição foi realizada para obter molaridade de 0,01 $\mu \mathrm{M}$. De maneira semelhante, as amostras contendo $\mathrm{LTB}_{4}$ foram preparadas.

Nicolete et al. (2007) determinaram que a concentração de $\mathrm{LTB}_{4}$ era de 0,5 $\mathrm{gg} / \mathrm{mL}$, o que representa uma molaridade de $1,5 \times 10^{-6} \mathrm{M}$. Assim, para obtenção de solução com molaridade de $1 \mu \mathrm{M}, 0,0012 \mathrm{~g}$ de massa total de microesferas foi acrescido em volume $6 \mathrm{~mL}$ de DMEM-i, sendo que a partir desta solução diluição foi realizada para obter a molaridade de $0,01 \mu \mathrm{M}$. 


\section{Análise da Contaminação de Microesferas}

\section{Teste de Esterilidade}

Para avaliação de contaminação por bactérias das microesferas preparadas foi realizado o teste de esterilidade. Para tanto, placas de Petri foram preparadas com ágar para cultura de bactérias. 0 ágar foi preparado conforme descrito na Tabela 2.

Tabela 2. Protocolo para preparo de Ágar

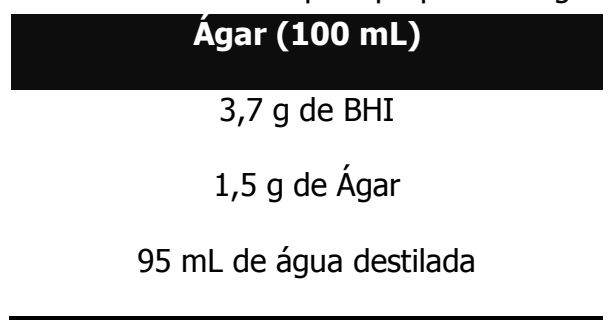

O ágar preparado foi autoclavado a $120^{\circ} \mathrm{C}$, por um período 15 minutos, e sequencialmente cerca de $8 \mathrm{~mL}$ foram dispensados em placas de Petri abertas em fluxo de cultura laminar. Após geleificação, as placas com ágar foram mantidas em estufa úmida a $37^{\circ} \mathrm{C}$ por um período de 24 horas para verificar a presença de contaminação durante 0 preparo das mesmas. Após este período, as placas foram envolvidas em filme plástico e estocadas em geladeira até uso.

Para a realização do teste de esterilidade propriamente dito, uma pequena quantidade das microesferas preparadas foi colocada em $500 \mu \mathrm{L}$ de solução salina fosfatada tamponada (PBS) e, após solubilização, $100 \mu \mathrm{L}$ da solução foram dispensados sobre a placa de Petri contendo ágar e espalhados por toda a área da mesma. Após estes passos, as placas foram mantidas em estufa úmida a $37^{\circ} \mathrm{C}$ por um período de 24 horas.

\section{Deteç̧ão de LPS}

Em fluxo de cultura laminar, $1 \mathrm{mg}$ de cada lote das microesferas preparadas e liofilizadas foi transferido com auxílio de espátula muflada para microtubos de $1,5 \mathrm{~mL}$ 
esterilizados e mantidos em freezer a $-20^{\circ} \mathrm{C}$ até o momento da realização do teste de contaminação por LPS.

Para tanto foi utilizado o kit Limulus Amebocyte Lysate (LAL) QCL-1000 ${ }^{\mathrm{TM}}$ (Lonza Walkersville, Inc., Olten, Switzerland) conforme instruções do fabricante, utilizando o método de microplacas.

As amostras pesadas e mantidas sob refrigeração foram diluídas na proporção $1: 1$ em água apirogênica, de modo a obter uma concentração de $1 \mu \mathrm{g} / \mathrm{mL}$. Para obtenção da curva, foi adotado o regime de diluição descrito na Tabela 3 da Endotoxina de $E$. coli 0111:B4 (E50-640). Para tanto, diluições seriadas da endotoxina foram realizadas a partir de $1,0 \mathrm{UE} / \mathrm{ml}$.

A microplaca onde foram realizados os testes foi previamente aquecida até atingir a temperatura de $37^{\circ} \mathrm{C}\left( \pm 1^{\circ} \mathrm{C}\right)$ e, sequencialmente, $50 \mu$ l das amostras foram pipetadas em seus respectivos poços, sendo realizadas duplicatas biológicas de cada amostra analisada. Ainda, como controle foram utilizados $50 \mu \mathrm{l}$ de LAL Reagent Water. Sequencialmente, $50 \mu \mathrm{l}$ de LAL foram adicionados por poço utilizando para tanto uma pipeta multicanal, e a microplaca incubada a $37^{\circ} \mathrm{C}$, onde permaneceu por 10 minutos. Neste momento, $100 \mu$ das soluções contendo os substratos previamente aquecidos foram pipetados e a microplaca novamente mantida sob as mesmas condições de incubação. Após 6 minutos, $100 \mu$ do reagente de parada da reação foram colocados em cada poço e a densidade óptica foi analisada em cada poço num comprimento de onda de 405 nm em espectrofotômetro Quant $^{\mathrm{TM}}$ (BioTek $^{\circledR}$ Instruments Inc., Winooski - USA), utilizando o software $\mathrm{KC}^{\mathrm{TM}}$ Data Analysis Software (BioTek ${ }^{\circledR}$ Instruments Inc., Winooski - USA), onde foi possível determinar a concentração de unidades de endotoxina a cada $\mathrm{mL}$ de solução contendo microesferas analisada ([EU/mL]). 
Tabela 3. Protocolo de diluição da E. coli 0111:B4 (E50-640)- Segundo fabricante (Lonza Inc.)

\begin{tabular}{cccc}
$\begin{array}{c}\text { Concentração da } \\
\text { Endotoxina } \\
\text { (EU/ml) }\end{array}$ & $\begin{array}{c}\text { Solução de } \\
\text { Estoque }\end{array}$ & $\begin{array}{c}\text { Solução Padrão } \\
\mathbf{1 , 0} \mathbf{~ E U / m l}\end{array}$ & $\begin{array}{c}\text { LAL Reagent } \\
\text { Water }\end{array}$ \\
\hline 1,0 & $0,1 \mathrm{~mL}$ & $-\mathrm{X}-1) / 10 \mathrm{~mL}$ \\
0,5 & - & $0,5 \mathrm{~mL}$ & $0,5 \mathrm{~mL}$ \\
0,25 & - & $0,5 \mathrm{~mL}$ & $1,5 \mathrm{~mL}$ \\
0,1 & $-1,0 \mathrm{~mL}$ & $0,9 \mathrm{~mL}$ \\
\hline
\end{tabular}

Para determinação da concentração de unidades de endotoxina em cada

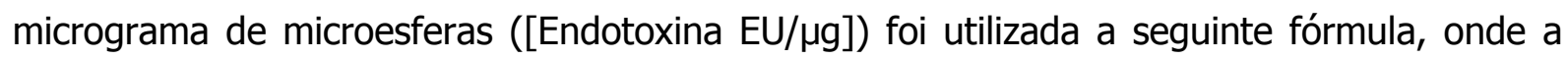
concentração da amostra após análise da densidade óptica era obtida em EU/mL, e a concentração da amostra inicial em $\mu \mathrm{g} / \mathrm{mL}$ :

$[$ Endotoxina $]=[$ Amostra Após Análise da Densidade Óptica $] \times \frac{1(\text { Diluição Adotada })}{[\text { Amostra Inicial }]}$

\section{Cultura de Células}

\section{Estudo em Cultura de Células Indiferenciadas da Polpa de Camundongos (OD-21)}

Células indiferenciadas da polpa são de extrema importância para o meio em que estão inseridas e isto se deve ao fato de apresentam a capacidade de proliferação e diferenciação em células odontoblásticas ativas, fato este que resulta na deposição de dentina e consequente manutenção da integridade estrutural deste tecido (Ferreira et al., 2015).

Para avaliar a expressão gênica nestas células frente a estímulos com mediadores lipídicos próinflamatórios $\left(\mathrm{LTB}_{4}\right.$ e $\left.\mathrm{PGE}_{2}\right)$, foram utilizadas células indiferenciadas da polpa de camundongos (OD-21), gentilmente cedidas pela Profa.Dra Karina Fittipaldi Bombonato Prado do Departamento de Morfologia, Fisiologia e Patologia da Faculdade de Odontologia de Ribeirão Preto (FORP/USP). 
Estas células foram mantidas congeladas em vial acondicionado em nitrogênio líquido (criopreservação) e conservadas em solução de congelamento composta por 90\% de Soro Fetal Bovino (FBS; Gibco, Carlsbad, CA, EUA) e 10\% de Dimetilsulfóxido (DMSO) (Mallinckodt Chemicals, Mallinckrodt Baker Inc., Phillipsburg, USA) até início da cultura.

As células foram descongeladas e o conteúdo presente no vial foi transferido para um tubo cônico (Falcon ${ }^{\mathrm{TM}}$,Corning Inc., NY, EUA) contendo $10 \mathrm{~mL}$ de DMEM com o penicilina $(100 \mu \mathrm{g} / \mathrm{ml})($ Gibco, EUA) e estreptomicina $(100 \mu \mathrm{g} / \mathrm{ml})$ (Gibco, EUA), suplementado com 10\% de FBS (DMEM-c). Após a transferência das células, o tubo cônico que as continha foi centrifugado a $1.200 \mathrm{rpm}$, por 10 minutos, a $10^{\circ} \mathrm{C}$. Após este passo, o sobrenadante foi descartado e as células constituintes do pellet foram ressuspendidas em $30 \mathrm{~mL}$ de meio DMEM-C.

As células foram transferidas para garrafa de cultura de $150 \mathrm{~cm}^{2}$ (Falcon ${ }^{\mathrm{TM}}$, Corning Inc., NY, EUA) e mantidas em estufa com controle de temperatura e pressão, $5 \%$ de $\mathrm{CO}_{2} \mathrm{e}$ fluxo de ar de 95\%, até atingirem $80 \%$ de confluência. O meio era trocado a cada 2-3 dias, sendo que a cada troca de meio de cultura a garrafa era lavada com $30 \mathrm{~mL}$ de solução salina fosfatada tamponada (PBS), a fim de remover debris e células mortas presentes na cultura.

Assim que a cultura atingiu a confluência, o meio de cultura foi retirado, e a garrafa foi lavada com $30 \mathrm{~mL}$ de PBS. Sequencialmente, $15 \mathrm{~mL}$ de DMEM-c foram colocados na garrafa, e com auxílio de um scraper esterilizado (Cell Scraper, Corning Glass Workers, NY, EUA), as células aderidas na superfície da garrafa foram destacadas. Após este passo, o sobrenadante foi transferido para um tubo cônico e centrifugado a 1.200 rpm, por 10 minutos, a $10^{\circ} \mathrm{C}$. Então, o sobrenadante foi descartado e o pellet ressuspendido em $10 \mathrm{~mL}$ de DMEM-C.

A contagem do número de células viáveis foi realizada em Câmara de Newbauer (BOECO Germany,Hamburg, Alemanha). Para tanto, $10 \mu \mathrm{L}$ da solução que contém as células 
foram adicionados a $90 \mu \mathrm{L}$ da solução de azul de Tripan (Gibco, NY, EUA), o que resulta em uma diluição na proporção 1:10.

As células, então, foram transferidas para placas de cultura celular de 96 poços para Ensaio de MTT na densidade de $1 \times 10^{5}$ células/poço e em placas de 48 poços na mesma densidade (Cell Wells, Corning Glass Workers, NY, EUA), para realização da avaliação da expressão gênica relativa. As placas de cultura foram mantidas em DMEM-c overnight em incubadora à temperatura de $37^{\circ} \mathrm{C}$, com $95 \%$ de ar e $5 \%$ de $\mathrm{CO}_{2}$.

Após este período o meio de cultura foi retirado e os poços lavados com PBS 1×. Posteriormente, os estímulos foram adicionados e as placas incubadas em estufa à temperatura de $37^{\circ} \mathrm{C}$, com $95 \%$ de ar e $5 \%$ de $\mathrm{CO}_{2}$ por 24 horas para ensaio de MTT, e quando realizada avaliação da expressão gênica relativa pelo período de 3, 6, 24, 48 e 72 horas, sendo que nestes períodos citados os estímulos foram removidos e o sobrenadante recolhido e mantido congelado a $-80^{\circ} \mathrm{C}$. As placas contendo as células também foram congeladas a $-80^{\circ} \mathrm{C}$ até o momento de realizar a avaliação da expressão de importantes genes para a síntese e mineralização da matriz dentinária Ibsp, Bmp2, Alpl, Bglap, Runx2 e Msx1 pelo método de Reação em Cadeia da Polimerase em Tempo Real.

\section{Teste de Viabilidade celular - Ensaio Colorimétrico MTT}

Após lavagem da garrafa de cultura com PBS $1 \times, 7 \mathrm{~mL}$ de Tripsina a 0,25\% com EDTA (Gibco) foram colocados na cultura e mantidos cerca de 2 minutos em estufa para cultura e esterilização à temperatura de $37^{\circ} \mathrm{C}$ e $5 \%$ de $\mathrm{CO}_{2}$. Após este período a tripsina foi neutralizada com $21 \mathrm{~mL}$ de DMEM-c e o conteúdo foi centrifugado a $1.500 \mathrm{rpm}$, por 10 minutos, a $4^{\circ} \mathrm{C}$.

Após contagem das células utilizando de método previamente descrito, as células foram plaqueadas em placas de cultura de 96 poços, a densidade de $1 \times 10^{5}$ células por poço, 
sendo mantidas em $200 \mu \mathrm{L}$ de meio DMEM-i incubadas a $37^{\circ} \mathrm{C}$ e $5 \%$ de $\mathrm{CO}_{2}$ overnight para adesão das mesmas.

Após este período o estímulo foi adicionado. Para tanto, utilizou-se de microesferas de $\mathrm{PGE}_{2}$ e $\mathrm{LTB}_{4}$ solubilizadas em DMEM-i com as seguintes molaridades: 0,01 $\mu \mathrm{M}$ e 0,1 $\mu \mathrm{M}$. Como controles negativos, foram utilizados DMEM-i e microesferas vazias (sem os mediadores lipídicos). Os estímulos foram mantidos por um período de 24 horas, quando os mesmos foram retirados e adicionada a solução de MTT [Brometo de 3-(4,5 dimetiltiazol-2il)2,5-difenil-tetrazólio], preparada conforme descrito na Tabela 5.

Tabela 4. Preparo da solução para teste de viabilidade.

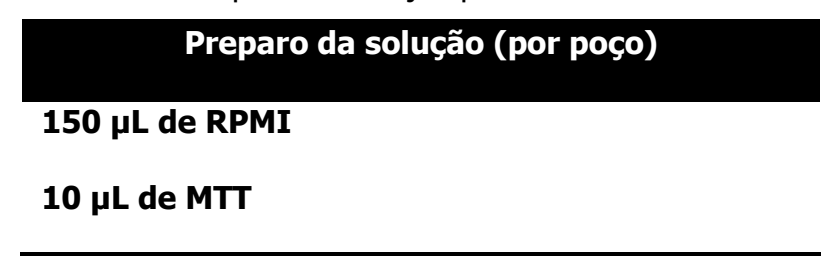

Assim, o meio de cultura foi substituído por RPMI (Roswell Park Memorial Institut) incolor (RPMI-I, cat. 11835030, $500 \mathrm{~mL}$ ) (Gibco, EUA) contendo o corante MTT - Brometo de 3-(4,5 dimetiltiazol-2il)-2,5-difenil-tetrazólio a 0,5 mg/mL (Ensaio Colorimétrico MTT Sigma M-5655), um sal que é reduzido por proteinases mitocontriais ativas somente em células viáveis. (Mosmann, 1983). As células foram incubadas por 3 horas envoltas em papel alumínio, quando então foram adicionados $40 \mu \mathrm{L}$ de Dodecil sulfato de sódio (SDS) $20 \%$ em $0,01 \mathrm{~N}$ de $\mathrm{HCl}$ em cada poço, sendo mantido à temperatura ambiente para solubilização completa do precipitado formado, para então proceder à medição colorimétrica em espectrofotômetro. A absorbância de cada poço foi determinada no comprimento de onda de 570 nm em espectrofotômetro SpectraMax ${ }^{\circ}$ Paradigm $®$ (Molecular Devices, LLC, Sunnyvale CA, USA). A viabilidade celular foi expressa em porcentagem e comparada ao controle (meio de cultura), o qual teve a absorbância obtida ajustada para $100 \%$ de viabilidade. 


\section{Estímulo Celular com Microesferas de Mediadores Lipídicos (LTB 4 e PGE )}

Inicialmente as microesferas preparadas pelo método de simples emulsão óleo-água seguido do processo de evaporação do solvente, como já descrito, foram pesadas e solubilizadas em DMEM incompleto de modo a obter as molaridades de 0,01 $\mu \mathrm{M}$ e $0,1 \mu \mathrm{M}$.

As células de linhagem OD-21 foram colocadas em placas de 48 poços à densidade de $1 \times 10^{5}$ células por poço e mantidas overnight em estufa a $37^{\circ} \mathrm{C}, 95 \%$ de oxigênio e $5 \%$ de $\mathrm{CO}_{2}$. Após este período, $300 \mu \mathrm{L}$ da solução contendo as microesferas foram adicionados aos poços das placas de cultura celular e mantidos pelo período de 3, 6, 24, 48 e 72 horas.

Após os períodos citados, o estímulo foi removido e o sobrenadante recolhido e mantido à temperatura de $-80^{\circ} \mathrm{C}$. Nas mesmas condições, as placas que continham as células foram congeladas até o momento de realização da avaliação da expressão gênica pelo método de Reação em Cadeia da Polimerase em Tempo Real.

\section{Avaliação da Expressão Gênica - Reação em Cadeia da polimerase em Tempo Real (RT-PCR) \\ Extração do RNA Total}

Para obtenção do RNA total foi realizado protocolo de extração à base de tiocianato de guanidina pelo método de colunas (RNeasy ${ }^{\circledR}$ Mini, Qiagen Inc., Valencia, EUA).

Para tanto, $350 \mu \mathrm{L}$ de solução tampão RLT (Qiagen) foram colocados em cada poço visando lisar as amostras. Foram adicionados ainda $350 \mu \mathrm{L}$ de álcool 70\%, previamente preparado com água livre de RNAse $\left(\right.$ Ambion $^{T M}$, Life Technologies, USA) com o intuito de permitir a ligação do RNA à membrana presente na coluna de purificação. Os $700 \mu \mathrm{L}$ de cada poço, então, foram transferidos para a coluna citada contendo tubo coletor acoplado e os tubos centrifugados a $10.000 \mathrm{rpm}$ por 15 segundos em microcentrífuga (Fanem ${ }^{\circledR}$ centrífuga micro mod. 243; São Paulo, Brasil). Os filtrados foram coletados, acondicionados em microtubos de $1,5 \mathrm{~mL}$ e mantidos à temperatura de $-20^{\circ} \mathrm{C}$. 
Na sequência, $350 \mu \mathrm{L}$ de solução tampão RW1 foram colocados na coluna de cada amostra, com a sequente centrifugação a $10.000 \mathrm{rpm}$ por 15 segundos. Após esta centrifugação, o filtrado foi descartado e mais $350 \mu \mathrm{L}$ de solução tampão RW1 foram colocados em cada coluna. Nova centrifugação foi realizada nas mesmas condições já citadas.

Sequencialmente, utilizou-se $500 \mu \mathrm{L}$ de solução tampão RPE contendo etanol, com a posterior centrifugação a $10.000 \mathrm{rpm}$ por 15 segundos. Novamente, $500 \mu \mathrm{L}$ de tampão RPE com etanol foram adicionados à coluna e os tubos centrifugados a $10.000 \mathrm{rpm}$, por 2 minutos. A fim de eliminar qualquer remanescente da solução tampão de RPE com etanol utilizado anteriormente, o tubo coletor foi descartado, a coluna montada em um novo tubo coletor e centrifugada a $10.000 \mathrm{rpm}$ por 1 minuto.

Para obtenção do RNA total, o tubo coletor foi descartado e as colunas acopladas à microtubos de $1,5 \mathrm{~mL}$. O RNA presente na membrana foi, então, eluído em $40 \mu \mathrm{L}$ de água livre de RNAse.

A pureza e a estimativa da quantidade de ácidos nucleicos foi realizada utilizando a espectrofotometria em NanoDrop 2000 (Thermo Fisher Scientific Inc., Wilmington, USA) e software NanoDrop 2000/2000c (Thermo Fisher Scientific Inc., Wilmington, USA), nos comprimentos de onda de 230, 260 e 280 nm.

\section{Transcrição Reversa (RT-PCR) - Síntese de RNA Complementar (cDNA)}

O cDNA foi sintetizado por meio de reação de transcrição reversa a partir de uma massa de 800 ng de RNA total. Para tanto, foi utilizado o kit High Capacity cDNA Reverse Transcription (Applied Biosystems, Foster City, EUA). Em tubos de 0,2 mL (Axygen Scientific, Inc.) foram adicionados ao RNA total $2,0 \mu \mathrm{L}$ de solução tampão $10 \times, 0,8 \mu \mathrm{L}$ de dNTP mixture $25 \times(100 \mathrm{mM}), 2,0 \mu \mathrm{L}$ de random primer $10 \times$ e $1,0 \mu \mathrm{L}$ da enzima Multiscribe ${ }^{\mathrm{TM}}$

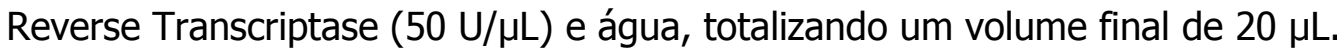


As amostras foram incubadas em termociclador (Veriti ${ }^{\circledR}$ Thermal Cycler, Applied Biosystems, USA) por 10 minutos a $25^{\circ} \mathrm{C}$ pra ligação do primer ao RNA, seguida de incubação a $37^{\circ}$ por 2 horas para transcrição reversa e incubação sequente a $85^{\circ} \mathrm{C}$ por 5 minutos para inativação da enzima transcriptase reversa e conclusão do processo. O cDNA resultante foi armazenado a temperatura de $-20^{\circ} \mathrm{C}$ até o momento do uso.

\section{Amplificação e Análise da Expressão Gênica em tempo Real - Reação em Cadeia da polimerase}

Para as reações de qRT-PCR foi utilizado o sistema TaqMan ${ }^{\circledR}$. Para tanto, alíquotas de $2 \mu \mathrm{L}$ de cDNA (o equivalente a $50 \mathrm{ng}$ de cDNA/poço) foram adicionadas a $10 \mu \mathrm{L}$ de $\operatorname{TaqMan}^{\circledR}$ Fast Advanced Master Mix (Applyed Biosystems, Life technologies, USA), $1 \mu \mathrm{L}$ de TaqMan $^{\circledR}$ Gene Expression Assay 20× (AB Applyed Biosystems, Life technologies, USA) (par de primers e sonda) e água livre de RNAse, totalizando um volume de $20 \mu \mathrm{L} /$ poço. Os pares de primers e sondas para Ibsp (Mm 00492555_m1), Alp/ (Mm 00475834_m1), Bglap (Mm 00649782_gH), Bmp2 (Mm 01340178_m1), Runx2 (Mm 00501584_m1) e Msx1 (Mm 00440330_m1) foram obtidos comercialmente e, portanto, suas sequências não estão disponíveis comercialmente. As concentrações finais dos primers eram de 900 nM cada e da sonda MGB (Minor Groove Binding) de 250 nM. Os genes para a enzima gliceraldeído-3fosfato desidrogenase (Gapdh) e proteína beta ( $\beta$ )-actina (Actb) foram utilizados como referências, sendo o fluoróforo 6-FAM utilizado como repórter e liberado após clivagem por meio da polimerase com atividade exonuclease $5^{\prime}$.

As soluções, então, foram distribuídas em placas de 96 poços (MicroAmp ${ }^{\circledR}$, Applied Biosystems), sendo o volume total de cada poço de $20 \mu \mathrm{L}$. As reações de qRT-PCR foram realizadas em duplicata utilizando o aparelho StepOne Plus ${ }^{\circledR}$ (StepOne Plus ${ }^{\circledR}$ Real-Time PCR System, Applied Biosystems). A amplificação da cadeia de cDNA foi iniciada com a ativação da polimerase AmpliTaq Gold Enzyme à temperatura de $95^{\circ} \mathrm{C}$ por 2 minutos, seguida por 40 
ciclos a $95^{\circ} \mathrm{C}$ por 1 segundo, para desnaturação do DNA, e $60^{\circ} \mathrm{C}$ por 20 segundos para anelamento dos primers e polimerização.

Os resultados foram analisados com base no valor do ciclo limiar (Ct; cycle threshold), valor correspondente ao número do ciclo no qual a amplificação das amostras atingiu um limiar, determinado entre o grau de fluorescência dos controles negativos e a fase de amplificação exponencial das amostras que permitiu a análise quantitativa da expressão do gene avaliado. Água livre de RNase foi utilizada como controle negativo e foi submetida à reação com cada par das sequências dos primers e sondas analisados.

O Ct determinado para cada amostra foi subtraído do Ct resultante da média geométrica dos genes de referência (Gapdh e $A c t b$ ) da mesma amostra. Desta forma, obteve-se o valor do $\Delta$ Ct. Para cada gene, a expressão relativa foi calculada a partir da diferença entre o valor do $\Delta \mathrm{Ct}$ de cada amostra e o $\Delta \mathrm{Ct}$ do controle ( $\Delta \Delta \mathrm{Ct})$, tendo como base a equação: $\mathbf{2}^{-\Delta \Delta C t}$.

\section{Análise Estatística}

Para comparação entre os valores da expressão gênica relativa de cada RNAm, assim como para avaliação da viabilidade celular (Ensaio MTT), foi utilizada a análise de variância de uma via (ANOVA) seguida pelo pós-teste de Tukey $(a=0,05)$. Os dados foram analisados utilizando, para tanto, o software GraphPad Prism 6 (GraphPad software Inc., La Jolla, USA). 

Resultados 



\section{RESULTADOS}

\section{Contaminação por Bactérias - Teste de Esterilidade}

Não foi constatada presença de contaminação bacteriana em nenhum lote de microesferas preparadas, sendo as mesmas utilizadas nos experimentos subsequentes. A cultura de microesferas em meio ágar por um período de 24 horas em estufa não revelou presença de qualquer tipo bacteriano, conforme é verificado nas Figuras 2 e 3.
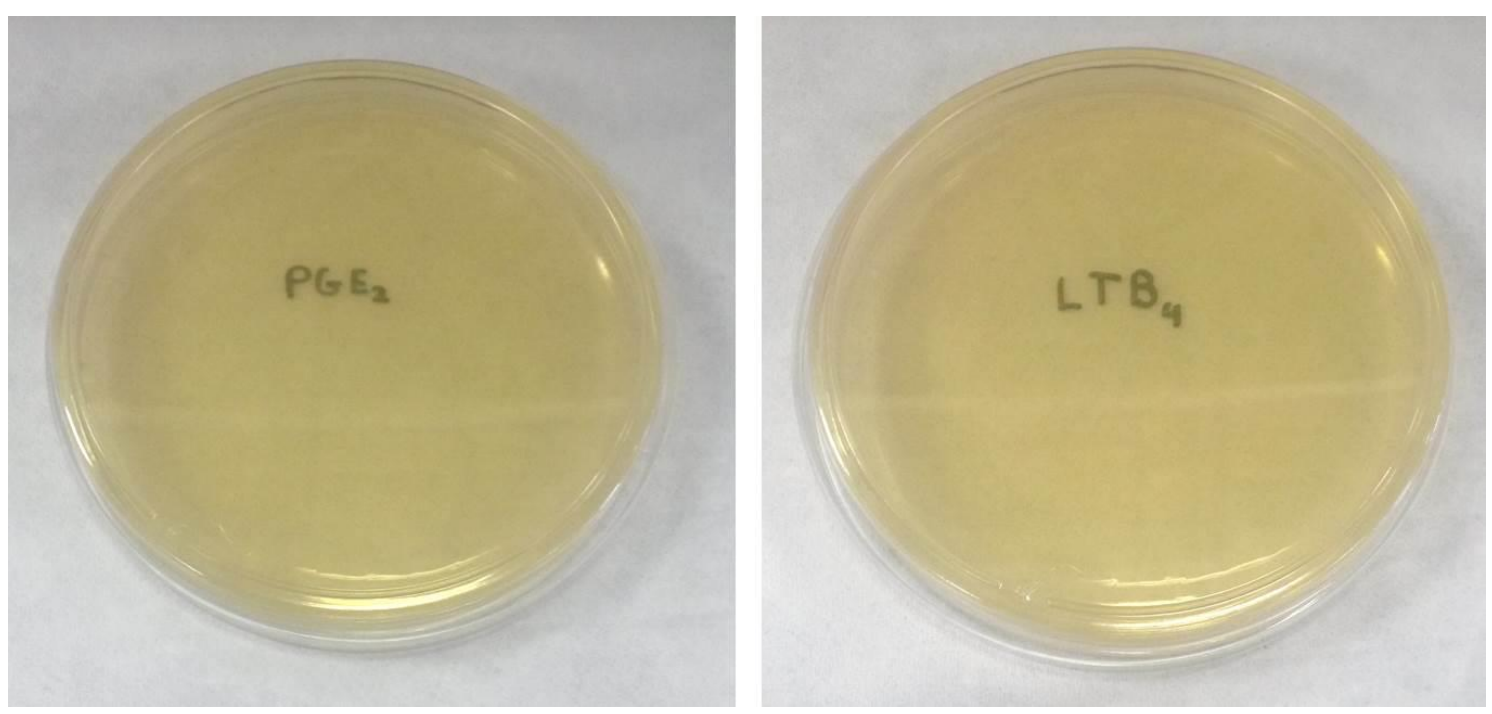

Figura 2. Cultura de microesferas contendo $\mathrm{LTB}_{4}$ e $\mathrm{PGE}_{2}$ em meio ágar após incubação por 24 horas.

Figura 3. Cultura de microesferas vazias em meio ágar após incubação por 24 horas. 


\section{Análise da presença de LPS nas microesferas}

A partir dos valores das concentrações obtidas e aplicação da fórmula previamente descrita, não foi detectada presença de LPS nas amostras de cada lote preparado. Portanto, as microesferas tanto vazias quanto com mediadores lipídicos encapsulados puderam ser utilizadas em todos os experimentos descritos.

Tabela 6. Concentração de endotoxina nas amostras.

\begin{tabular}{|c|c|c|c|}
\hline Amostra & $\begin{array}{c}\text { [Endotoxina] } \\
\text { EU/pg }\end{array}$ & Amostra & $\begin{array}{c}\text { [Endotoxina] } \\
\text { EU/ug }\end{array}$ \\
\hline Lote 1 LTB $_{4}$ & 0,0003011 & Lote $2 \mathrm{PGE}_{2}$ & 0,0002648 \\
\hline Lote 1 LTB $_{4}$ & 0,0002784 & Lote $3 \mathrm{PGE}_{2}$ & 0,0003434 \\
\hline Lote 2 LTB $_{4}$ & 0,0001771 & Lote $3 \mathrm{PGE}_{2}$ & 0,0002724 \\
\hline Lote 2 LTB $_{4}$ & 0,0001771 & Lote $4 \mathrm{PGE}_{2}$ & 0,0001938 \\
\hline Lote 3 LTB $_{4}$ & 0,0002725 & Lote $4 \mathrm{PGE}_{2}$ & 0,0001741 \\
\hline Lote 3 LTB $_{4}$ & 0,0001953 & Lote $5 \mathrm{PGE}_{2}$ & 0,0002346 \\
\hline Lote $4 \mathrm{LTB}_{4}$ & 0,0002663 & Lote $5 \mathrm{PGE}_{2}$ & 0,0003873 \\
\hline Lote 4 LTB $_{4}$ & 0,0002784 & Lote $6 \mathrm{PGE}_{2}$ & 0,0005339 \\
\hline Lote $5 \mathrm{LTB}_{4}$ & 0,0003555 & Lote $6 \mathrm{PGE}_{2}$ & 0,0002270 \\
\hline Lote 5 LTB $_{4}$ & 0,0002452 & Lote 1 MS-Vazia & 0,0001469 \\
\hline Lote $1 \mathrm{PGE}_{2}$ & 0,0003389 & Lote 1 MS-Vazia & 0,0001136 \\
\hline Lote $1 \mathrm{PGE}_{2}$ & 0,0001817 & Lote 2 MS-Vazia & 0,0001424 \\
\hline Lote $2 \mathrm{PGE}_{2}$ & 0,0003253 & Lote 2 MS-Vazia & 0,0001393 \\
\hline
\end{tabular}

Como foi possível observar, não foi detectado LPS nas amostras, pois os valores obtidos se encontram abaixo do limite aceitável de detecção da técnica, que corresponde a $0,1 \mathrm{EU} / 1 \mu \mathrm{g}$ de polímero.

\section{Teste de Viabilidade celular - Ensaio MTT}

$\underline{\mathrm{O} \text { tratamento com } \mathrm{PGE}_{2} \text { levou à proliferação celular após um período de incubação de } 24}$ horas. 
Figura 4.

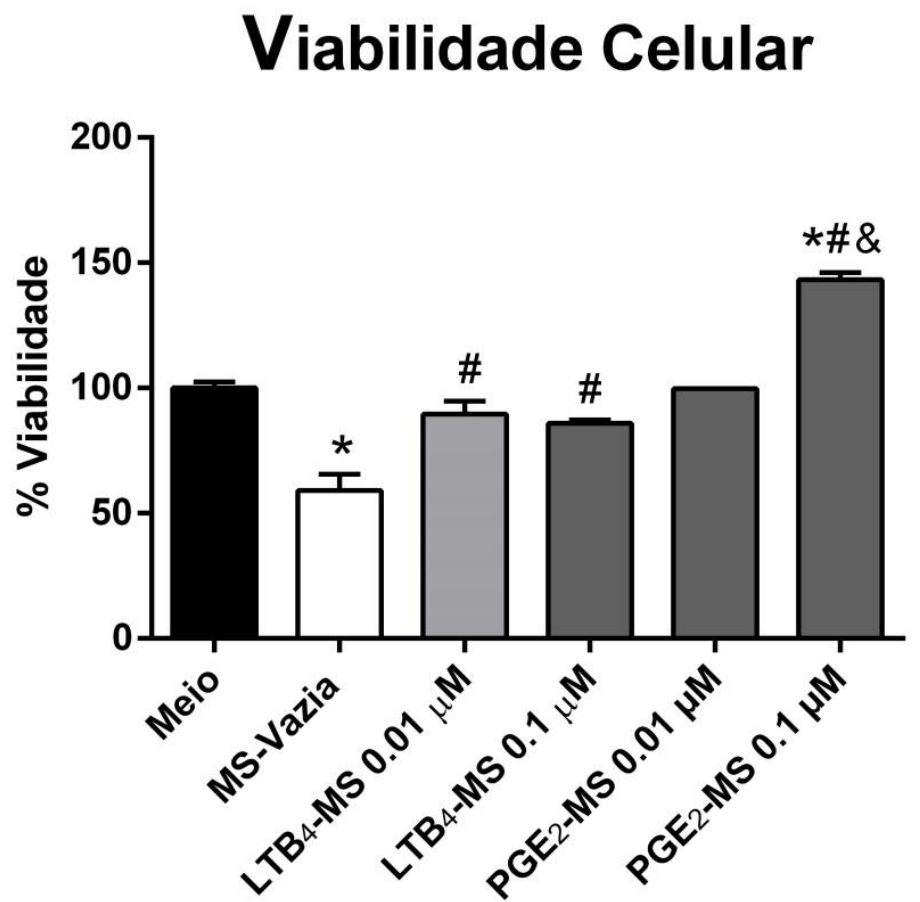

Figura 4. Efeito das diferentes molaridades dos mediadores encapsulados e de microesferas vazias na viabilidade celular em cultura de células indiferenciadas da polpa dental (OD-21) por meio do teste MTT após 24 horas de exposição. ${ }^{*} p<0,05$ comparado ao controle; ${ }^{*} p<0,05$ comparado ao controle, ${ }^{\#} p<0,05$ comparado à microesfera vazia; ${ }^{2} p<0,05$ comparação entre $\mathrm{LTB}_{4}$ e $\mathrm{PGE}_{2}$ na mesma molaridade.

Quando os tratamentos foram comparados ao grupo controle, foi possível observar aumento no número de células viáveis no tratamento com $\mathrm{PGE}_{2}$, o que indica proliferação celular. No entanto, o tratamento com microesferas vazias reduziu o número de células viáveis na cultura.

Ao comparar cada tratamento com suas microesferas vazias também foi possível observar diferenças estatisticamente significantes. Ao se utilizar microesferas de $\mathrm{LTB}_{4}$ de 0,01 $\mu \mathrm{M}$ e 0,1 $\mu \mathrm{M}$, o número de células viáveis se revelou superior ao de microesferas vazias. Quando comparamos os grupos de $\mathrm{PGE}_{2}$, o grupo de maior molaridade revelou maior número de células viáveis quando comparado às microesferas vazias.

Foram constatadas diferenças estatisticamente significantes, ainda, entre as diferentes classes de mediadores lipídicos, onde tais diferenças foram observadas entre a 
maior molaridade de $\mathrm{LTB}_{4}$ e PGE 2 . Nestes casos, o número de células viáveis foi observado de maneira mais expressiva quando foi realizado tratamento com $\mathrm{PGE}_{2}$ de molaridades 0,1 $\mu \mathrm{M}$, de modo que o $\mathrm{LTB}_{4}$ mostrou menor número de células ao comparar com sua molaridade correspondente de $\mathrm{PGE}_{2}$.

\section{Avaliação da Expressão Gênica - Reação em Cadeia da Polimerase em Tempo Real (RT-PCR)}

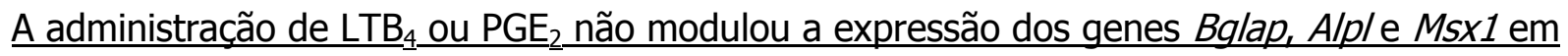
nenhum grupo

Após a realização de qRT-PCR foi demonstrado que o tratamento com mediadores lipídicos utilizados neste estudo em todos os grupos e períodos experimentais não modulou a expressão dos genes Bglap, Alpl e Msx1, todos envolvidos na síntese e mineralização da matriz dentinária.

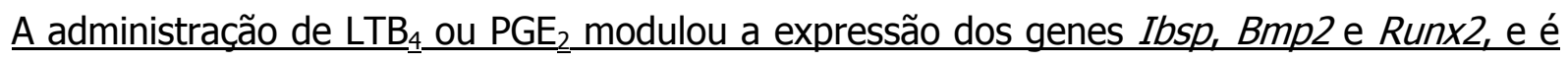
dependente do período e do grupo analisados.

Após a realização de qRT-PCR foi demonstrado que o tratamento com os mediadores lipídicos $\left(\mathrm{LTB}_{4}\right.$ ou $\left.\mathrm{PGE}_{2}\right)$ modulou diferencialmente a expressão dos genes Ibsp, Bmp2 e Runx2, envolvidos na síntese e mineralização da matriz dentinária, a depender do período experimental analisado, bem como do tipo de tratamento recebido pelas células.

A expressão relativa do gene Ibsp após um período de estimulação de 3 horas com as diferentes classes de mediadores lipídicos, bem como com microesferas vazias é apresentada na Figura 5. 


\section{$\operatorname{lbsp}(3 \mathrm{~h})$}

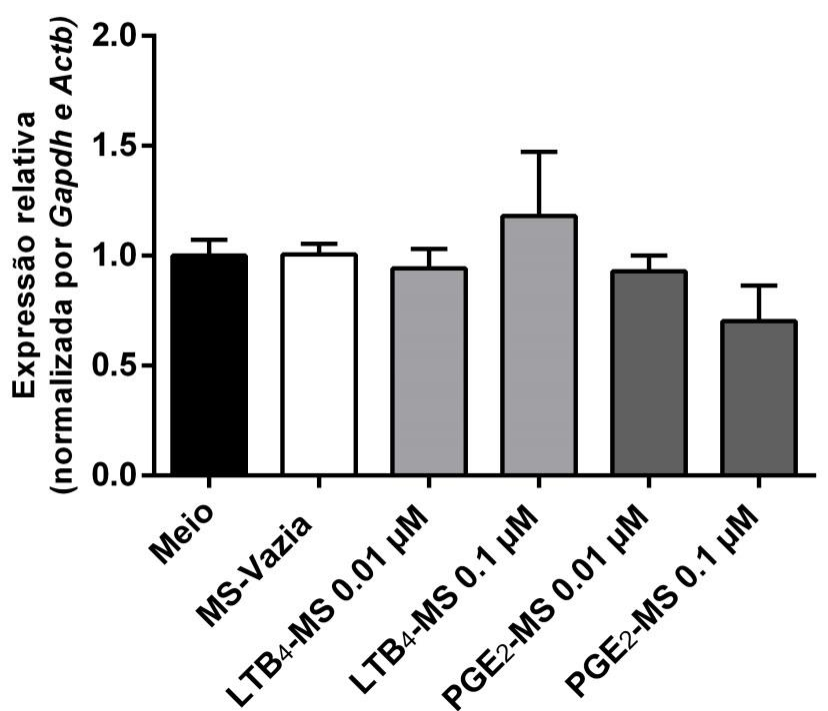

Figura 5. Expressão relativa do gene Ibsp após um período de estimulação de 6 horas com $\mathrm{LTB}_{4}$, $\mathrm{PGE}_{2} \mathrm{e}$ microesferas vazias. ${ }^{*} \mathrm{p}<0,05$ comparado ao controle; ${ }^{\#} \mathrm{p}<0,05$ comparado à microesfera vazia; ${ }^{\mathrm{p}}<<0,05$ comparação entre $\mathrm{LTB}_{4}$ e $\mathrm{PGE}_{2}$ na mesma molaridade.

Após este período experimental, não foi possível observar diferenças estatisticamente significantes entre os diferentes grupos avaliados, o que também pôde ser observado nos grupos avaliados após um período de estimulação de 6 horas, conforme observado na Figura 6.

\section{Ibsp (6h)}

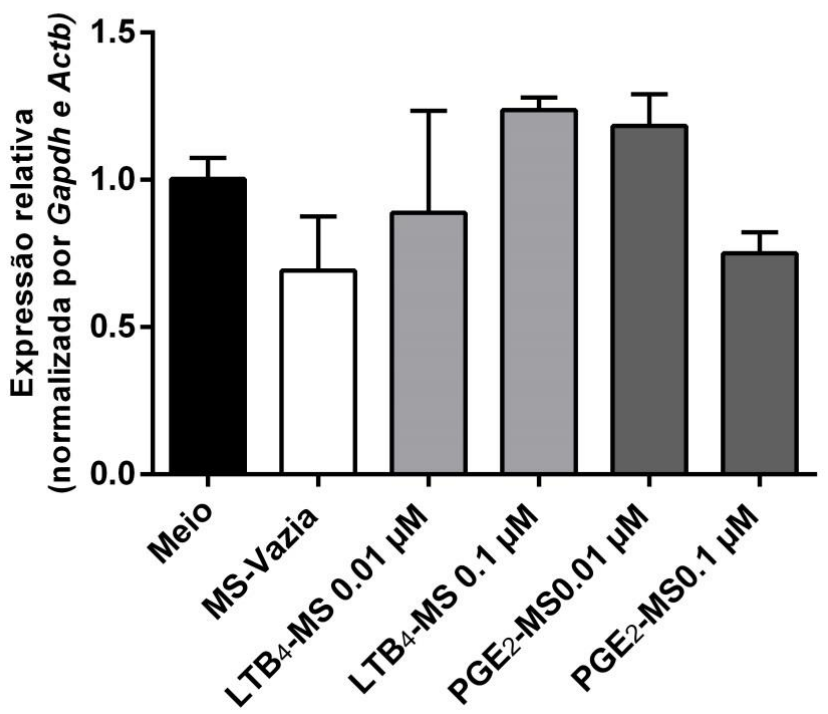

Figura 6. Expressão relativa do gene Ibsp após um período de estimulação de 6 horas com $\mathrm{LTB}_{4}, \mathrm{PGE}_{2} \mathrm{e}$ microesferas vazias. ${ }^{*} p<0,05$ comparado ao controle; ${ }^{*} p<0,05$ comparado à microesfera vazia; ${ }^{\&} p<0,05$ comparação entre $\mathrm{LTB}_{4}$ e $\mathrm{PGE}_{2}$ na mesma molaridade. 
Por outro lado, foi possível observar diferenças estatisticamente significantes na expressão gênica do Ibsp após um período de 24 horas de estimulação com os diferentes tratamentos (Figura 7). Neste período foi possível observar redução da expressão gênica de Ibsp em relação ao grupo controle nas células estimuladas com $\mathrm{LTB}_{4}$ nas diferentes molaridades utilizadas. Por outro lado, após um período de estimulação de 24 horas com $\mathrm{PGE}_{2}$ encapsuladas e de menor molaridade, as células tiveram uma tendência a aumentar a expressão de Ibsp pois, apesar de esta diferença não ter sido estatisticamente significante em relação ao grupo controle, o foi em relação ao grupo de microesferas vazias, bem como em relação a seu grupo correspondente de $\mathrm{LTB}_{4}$.

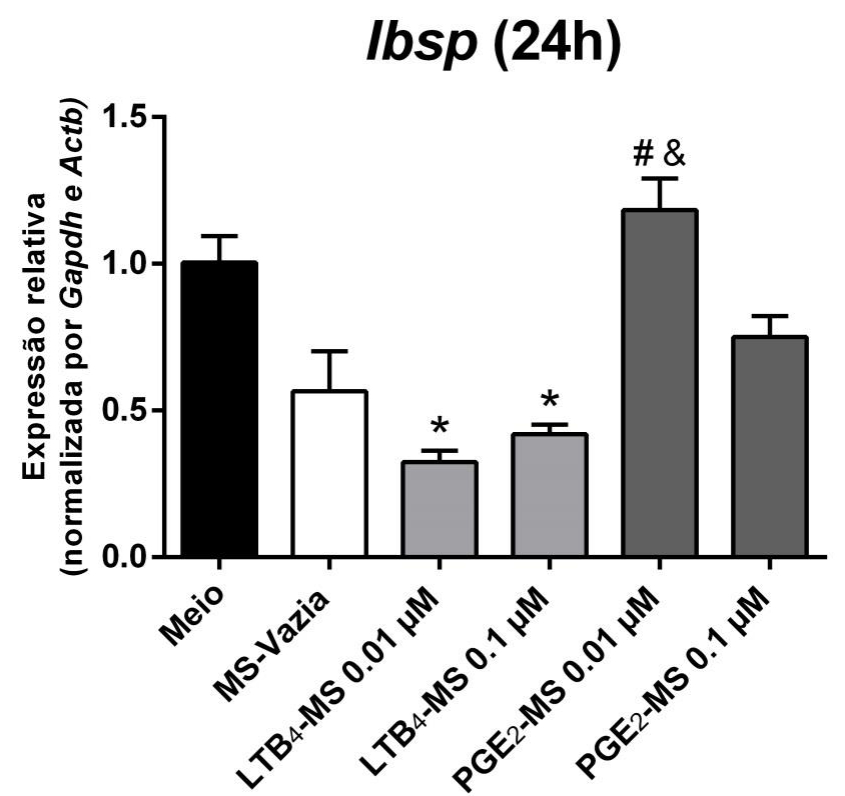

Figura 7. Expressão relativa do gene Ibsp após um período de estimulação de 24 horas com $\mathrm{LTB}_{4}, \mathrm{PGE}_{2}$ e microesferas vazias. ${ }^{*} p<0,05$ comparado ao controle; ${ }^{\#} p<0,05$ comparado à microesfera vazia; ${ }^{*} p<0,05$ comparação entre $\mathrm{LTB}_{4}$ e $\mathrm{PGE} 2$ na mesma molaridade.

Após um período de estimulação de 48 e 72 horas, não houve diferenças estatisticamente significantes dos tratamentos avaliados em relação ao grupo controle, como observado nas Figuras 8 e 9. 


\section{Ibsp (48h)}

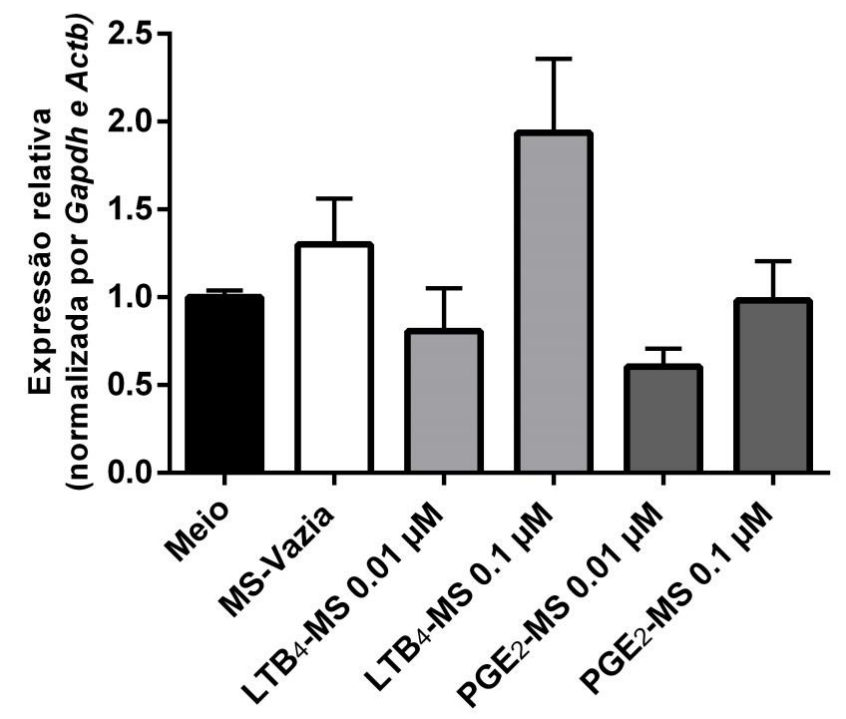

Figura 8. Expressão relativa do gene $I b s p$ após um período de estimulação de 48 horas com $L_{T B}{ }_{4}, P^{2} E_{2}$ e microesferas vazias. ${ }^{*} p<0,05$ comparado ao controle; ${ }^{*} p<0,05$ comparado à microesfera vazia; ${ }^{*} p<0,05$ comparação entre $\mathrm{LTB}_{4}$ e $\mathrm{PGE}_{2}$ na mesma molaridade.

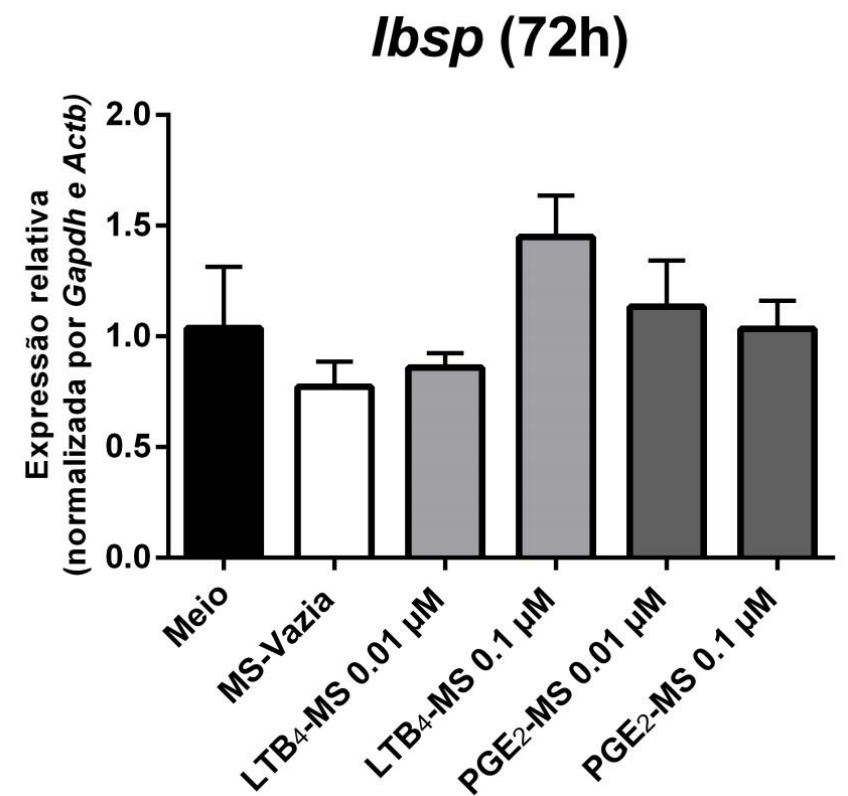

Figura 9. Expressão relativa do gene Ibsp após um período de estimulação de 72 horas com $\mathrm{LTB}_{4}, \mathrm{PGE}_{2} \mathrm{e}$ microesferas vazias. ${ }^{*} p<0,05$ comparado ao controle; ${ }^{*} p<0,05$ comparado à microesfera vazia; ${ }^{*} p<0,05$ comparação entre $\mathrm{LTB}_{4}$ e $\mathrm{PGE}_{2}$ na mesma molaridade.

Com relação à expressão de $B m p 2$, não foram observadas diferenças estatisticamente significantes nos períodos de tratamento de 3 horas, conforme observado na Figura 10. 


\section{Bmp2 (3h)}

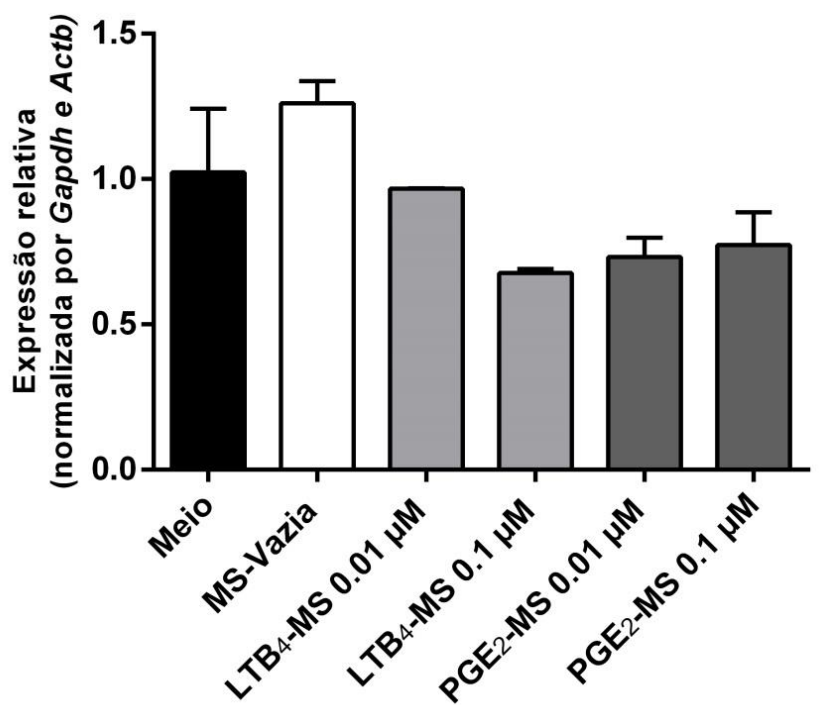

Figura 10. Expressão relativa do gene $B m p 2$ após um período de estimulação de 3 horas com $\mathrm{LTB}_{4}, \mathrm{PGE}_{2}$ e microesferas vazias. ${ }^{*} p<0,05$ comparado ao controle; ${ }^{\#} p<0,05$ comparado à microesfera vazia; ${ }^{*} p<0,05$ comparação entre $\mathrm{LTB}_{4}$ e $\mathrm{PGE}_{2}$ na mesma molaridade.

Por outro lado, como é possível observar na Figura 11, microesferas de $\mathrm{PGE}_{2}$ de 0,1 $\mu \mathrm{M}$ revelaram aumento na expressão gênica de $B m p 2$ em relação ao grupo controle após um período experimental de 6 horas. Contudo, conforme constatado, microesferas de $\mathrm{LTB}_{4}$ de molaridade $0,1 \mu \mathrm{M}$ promovem inibição da expressão do gene citado quando comparado ao mesmo grupo de $\mathrm{PGE}_{2}$, ou seja, a $\mathrm{PGE}_{2}$ de molaridade $0,1 \mu \mathrm{M}$ teve maior expressão gênica quando comparada a seu grupo correspondente de $\mathrm{LTB}_{4}$. Esta diferença se revelou de forma estatisticamente significante, ainda, quando se comparou o grupo de $\mathrm{PGE}_{2}$ de maior molaridade ao grupo de microesferas vazias, no qual o mediador encapsulado apresentou maior expressão gênica de Bmp2. 


\section{Bmp2 (6h)}

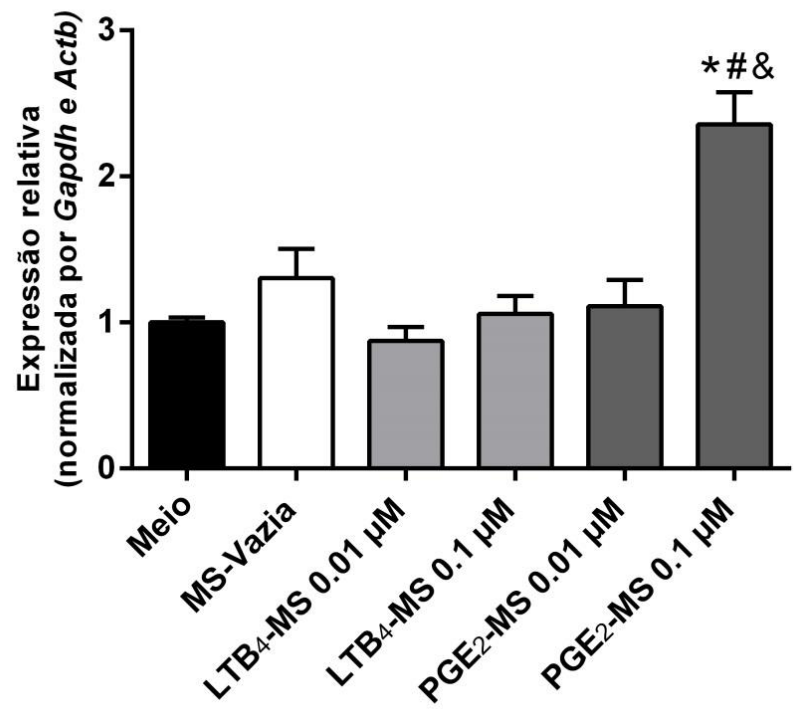

Figura 11. Expressão relativa do gene $B m p 2$ após um período de estimulação de 6 horas com $L_{T B}$, $P G E_{2}$ e microesferas vazias. ${ }^{*} p<0,05$ comparado ao controle; ${ }^{\#} p<0,05$ comparado à microesfera vazia; ${ }^{*} p<0,05$ comparação entre $\mathrm{LTB}_{4}$ e $\mathrm{PGE}_{2}$ na mesma molaridade.

Ao avaliar a expressão de Bmp2 após estimulação por 24, 48 e 72 horas, nenhuma diferença estatisticamente significante foi observada (Figuras 12 , 13 e 14).

\section{Bmp2 (24h)}

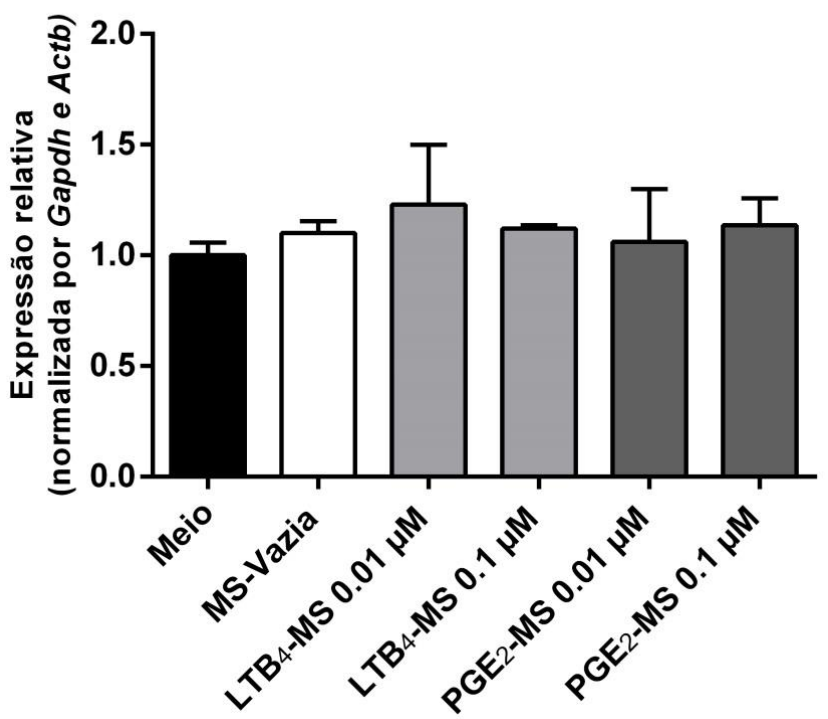

Figura 12. Expressão relativa do gene Bmp2 após um período de estimulação de 24 horas com $\mathrm{LTB}_{4}, \mathrm{PGE}_{2} \mathrm{e}$ microesferas vazias. ${ }^{*} p<0,05$ comparado ao controle; ${ }^{\#} p<0,05$ comparado à microesfera vazia; ${ }^{p}<<0,05$ comparação entre $\mathrm{LTB}_{4}$ e $\mathrm{PGE}_{2}$ na mesma molaridade. 


\section{Bmp2 (48h)}

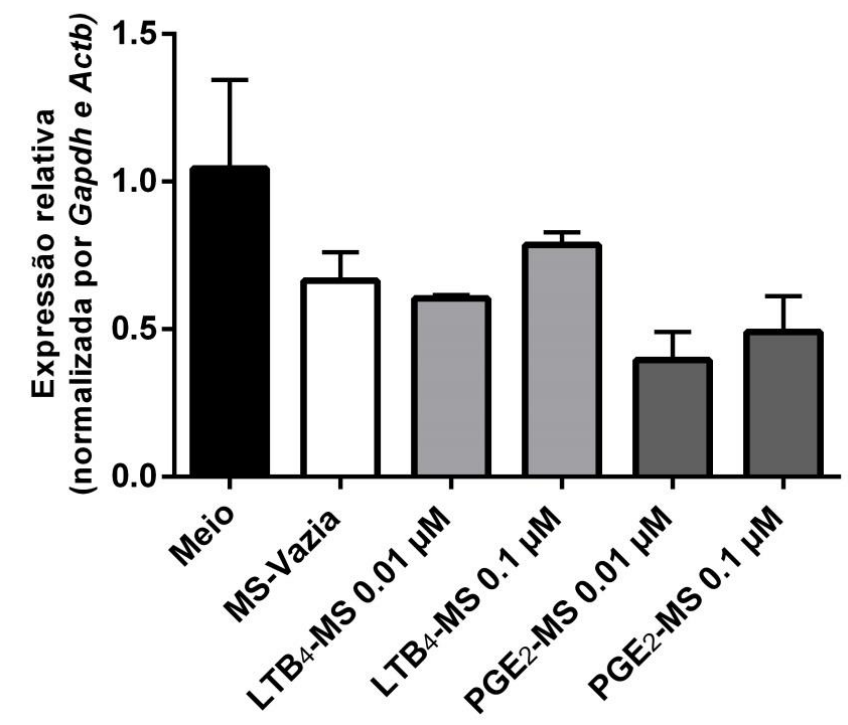

Figura 13. Expressão relativa do gene $B m p 2$ após um período de estimulação de 48 horas com LTB4, PGE2 e microesferas vazias. ${ }^{*} p<0,05$ comparado ao controle; $\# p<0,05$ comparado à microesfera vazia; $\& p<0,05$ comparação entre LTB4 e PGE2 na mesma molaridade.

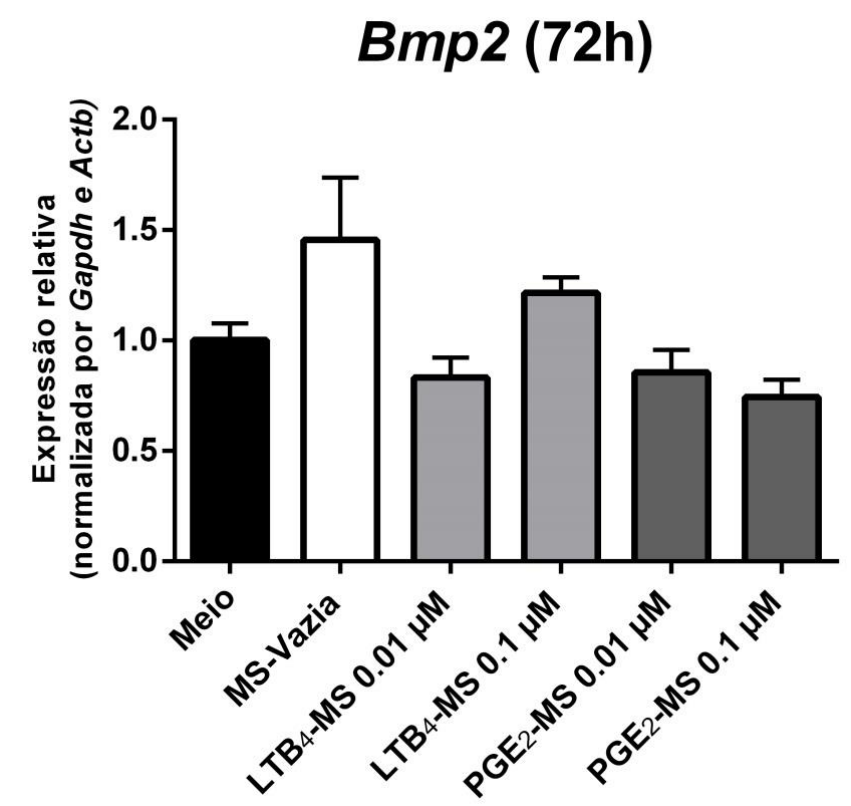

Figura 14. Expressão relativa do gene $B m p 2$ após um período de estimulação de 72 horas com LTB4, PGE2 e microesferas vazias. ${ }^{*} p<0,05$ comparado ao controle; $\# p<0,05$ comparado à microesfera vazia; \&p<0,05 comparação entre LTB4 e PGE2 na mesma molaridade.

Ainda foi avaliada a expressão gênica de Runx2 nos diferentes períodos experimentais já citados.

Conforme é possível observar na Figura 15, a expressão de Runx2 não foi diferente de maneira estatisticamente significante entre os diferentes tipos de tratamentos avaliados 
após um período de estimulação com os mesmos de 3 horas, diferentemente do que ocorre após um período experimental de 6 horas, como observado na Figura 16.

\section{Runx2 (3h)}

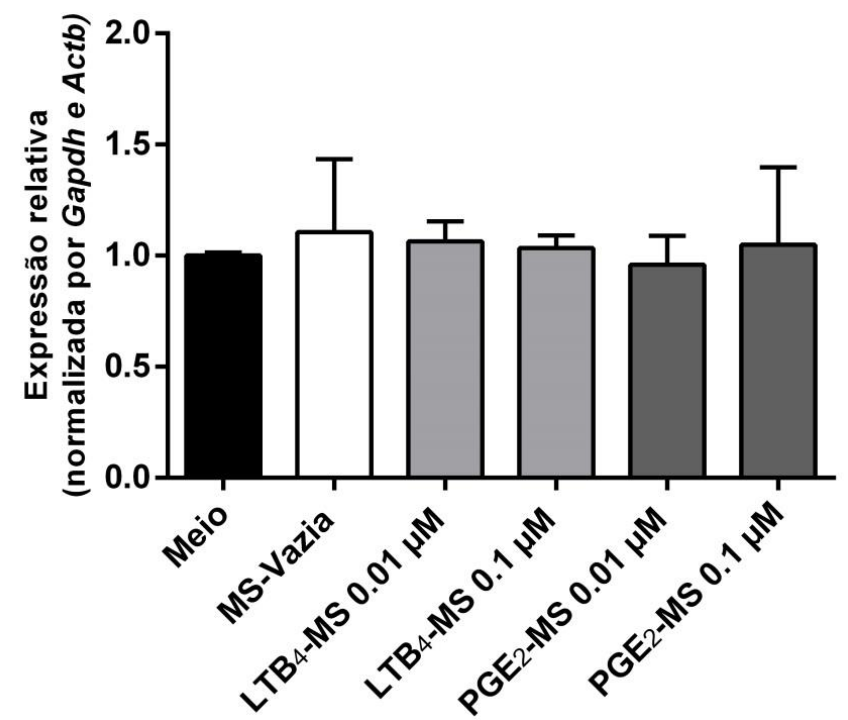

Figura 15. Expressão relativa do gene Runx 2 após um período de estimulação de 3 horas com $\mathrm{LTB}_{4}, \mathrm{PGE}_{2} \mathrm{e}$ microesferas vazias. ${ }^{*} p<0,05$ comparado ao controle; ${ }^{\#} p<0,05$ comparado à microesfera vazia; ${ }^{*} p<0,05$ comparação entre $\mathrm{LTB}_{4}$ e $\mathrm{PGE}_{2}$ na mesma molaridade.

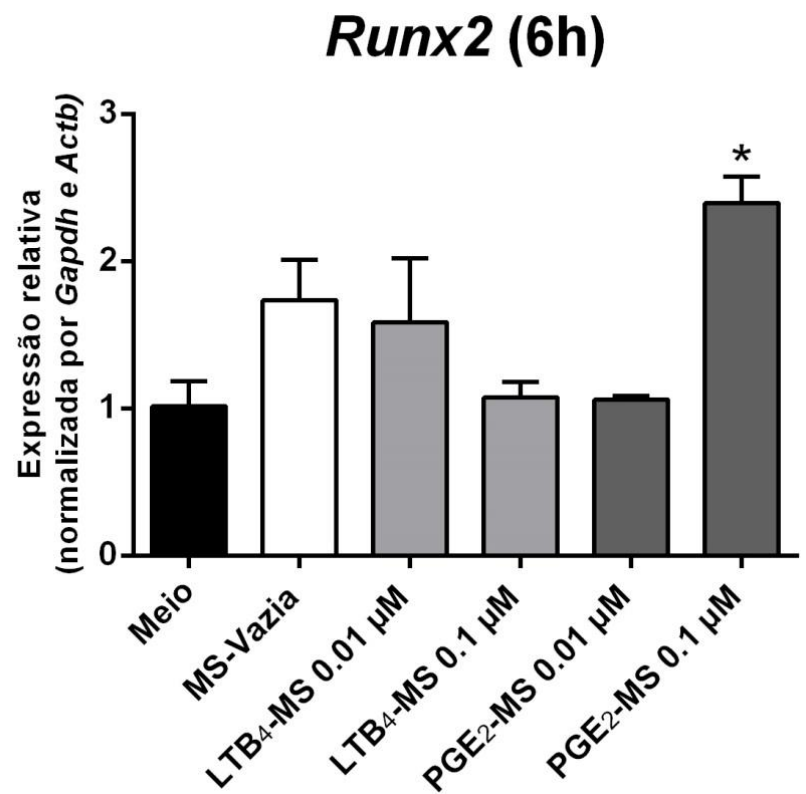

Figura 16. Expressão relativa do gene Runx2 após um período de estimulação de 6 horas com LTB4, PGE2 e microesferas vazias. ${ }^{*} p<0,05$ comparado ao controle; $\# p<0,05$ comparado à microesfera vazia; $\& p<0,05$ comparação entre LTB4 e PGE2 na mesma molaridade. 
Após estimulação por 6 horas a expressão de Runx2 foi aumentada, em relação ao grupo controle, quando as células foram tratadas com microesferas contendo $\mathrm{PGE}_{2}$ a $0,1 \mu \mathrm{M}$, o que não ocorreu após período de estimulação de 24 horas (Figura 17), onde não foi possível observar diferenças estatisticamente significantes entre os diferentes tratamentos aplicados.

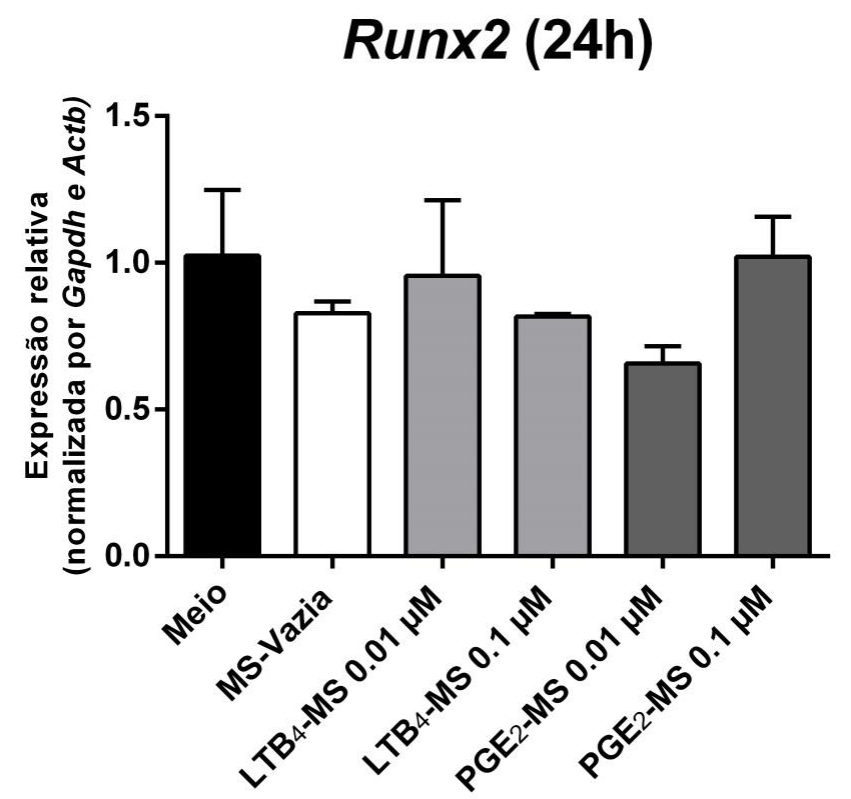

Figura 17. Expressão relativa do gene Runx2 após um período de estimulação de 24 horas com $\mathrm{LTB}_{4}, \mathrm{PGE}_{2} \mathrm{e}$ microesferas vazias. ${ }^{*} p<0,05$ comparado ao controle; ${ }^{*} p<0,05$ comparado à microesfera vazia; ${ }^{*} p<0,05$ comparação entre $\mathrm{LTB}_{4}$ e $\mathrm{PGE}_{2}$ na mesma molaridade.

A expressão gênica de Runx2 após um período de estimulação de 48 horas, contudo, mostrou diferença estatisticamente significante entre o grupo que recebeu tratamento com microesferas vazias e o grupo controle, sendo que o grupo de microesferas vazias teve a expressão de Runx2 aumentada (Figura 18). Além disso, a expressão do gene citado foi diminuída em células tratadas com $\mathrm{LTB}_{4}$ a $0,01 \mu \mathrm{M}$ em relação ao grupo de microesferas vazias. Esta redução na expressão gênica em relação ao grupo de microesferas vazias também pôde ser observada no grupo de células tratadas com microesferas de $\mathrm{PGE}_{2} \mathrm{a}$ $0,1 \mu \mathrm{M}$. 


\section{Runx2 (48h)}

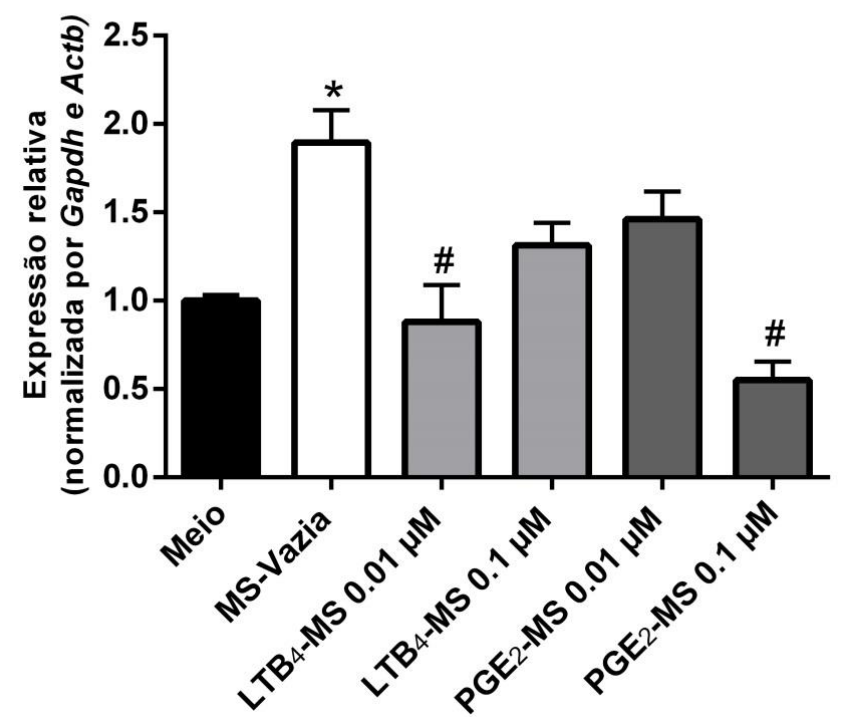

Figura 18. Expressão relativa do gene Runx2 após um período de estimulação de 48 horas com $\mathrm{LTB}_{4}, \mathrm{PGE}_{2} \mathrm{e}$ microesferas vazias. ${ }^{*} \mathrm{p}<0,05$ comparado ao controle; ${ }^{\#} \mathrm{p}<0,05$ comparado à microesfera vazia; ${ }^{\mathrm{p}} \mathrm{p}<0,05$ comparação entre $\mathrm{LTB}_{4}$ e $\mathrm{PGE}_{2}$ na mesma molaridade.

No entanto, ao avaliar a expressão de Runx2 após 72 horas de estimulação, nenhuma diferença estatisticamente significante oi observada entre os diferentes tratamentos (Figura 19).

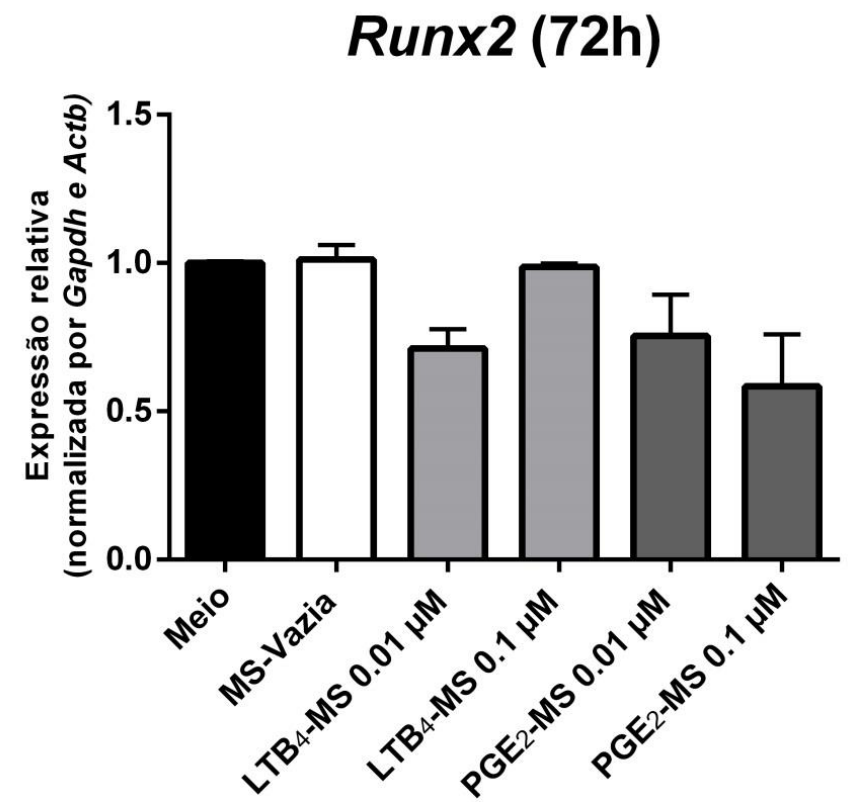

Figura 19. Expressão relativa do gene Runx2 após um período de estimulação de 72 horas com $L_{T B}$, $P G E_{2}$ e microesferas vazias. ${ }^{*} p<0,05$ comparado ao controle; ${ }^{\#} p<0,05$ comparado à microesfera vazia; ${ }^{*} p<0,05$ comparação entre $\mathrm{LTB}_{4}$ e $\mathrm{PGE}_{2}$ na mesma molaridade. 

$D_{\text {iscussão }}$ 



\section{DISCUSSÃO}

O processo inflamatório é importante para combater infecções e se mostra essencial para proteger o tecido de lesões e restabelecer o seu funcionamento fisiológico (Gylroy et al., 2010). Citocinas e diversas moléculas de sinalização são sintetizadas e secretadas pelas células hospedeiras do complexo dentino-pulpar antes do recrutamento e ativação das células do sistema imune, o que revela que previamente à resposta imune celular, o complexo dentino-pulpar gera um padrão de resposta imune molecular (Cooper et al., 2011)

Assim, a resposta imune voltada a processos infecciosos envolve mecanismos moleculares complexos com ações coordenadas, sendo os eicosanoides mediadores lipídicos derivados do ácido araquidônico capazes de regular processos homeostáticos e inflamatórios. No entanto, a quantidade de eicosanoides produzidos está na dependência do estado de ativação e da condição fisiológica do tecido (Dennis e Norris, 2015). Por isso, o presente estudo foi conduzido de maneira a utilizar diferentes molaridades dos mediadores estudados.

A opção pelo método de encapsulação foi escolhida porque, desta forma, o mediador lipídico teve sua atividade biológica preservada, além de constituir uma importante ferramenta de estímulo celular, de modo a proteger o mediador encapsulado da degradação (Nicolete et al., 2008b). Após avaliação por um período de 24 horas, sabe-se que microesferas de $\mathrm{LTB}_{4}$ tiveram pico de liberação de $45 \%$ do mediador num período de 5 horas, podendo ser continuamente liberado por um longo período de tempo (Nicolete et al., 2007). No tocante à $\mathrm{PGE}_{2}$, o pico de liberação ocorreu nas primeiras 4 horas, também podendo ser liberada continuamente em períodos mais longos (Nicolete et al., 2008a), onde já foi constatada liberação de produtos encapsulados por um período de até 21 dias e manutenção dos efeitos biológicos sobre as células estimuladas (Mathieu et al., 2013).

As microesferas foram preparadas utilizando como arcabouço um polímero, mais especificamente o ácido poli-lático co-glicólico (PLGA). O PLGA é amplamente utilizado no 
preparo de microesferas por ser um polímero biodegradável e biocompatível (Fredenberg et al., 2011). Este material permite liberação das moléculas encapsuladas de maneira controlada por longos períodos e a partir de uma única administração, o que mantém as concentrações da substância encapsulada constantes (Ford Versypt et al., 2012).

$\mathrm{O} \mathrm{LTB}_{4}$ e a PGE 2 já foram eficientemente encapsulados em PLGA sem que houvesse prejuízo no que diz respeito à sua atividade biológica, pois polímeros de ácido láctico/glicólico apresentam elevada eficiência de encapsulação e adequada estabilidade. Os produtos da degradação do PLGA são biocompatíveis, e consistem em ácido láctico e glicólico (Pereira et al., 2015). Estes produtos da degradação, no entanto, constituem importantes metabólitos celulares (Mikos et al., 1994). Isso poderia explicar o aumento da expressão gênica de Runx2 observada após um período de estimulação de 48 horas em que se utilizou microesferas vazias, além da redução no número de células viáveis após estimulação com as mesmas em ensaio colorimétrico MTT. Nestes casos, os produtos da degradação do polímero, que como antes citado, provavelmente atuaram diretamente sobre o metabolismo celular e foram capazes de alterá-lo o que, consequentemente, afetou o padrão de resposta celular. Estudo prévio que se utilizou de microesferas vazias em macrófagos derivados da medula óssea de camundongos mostrou que mesmo células estimuladas com microesferas vazias também foram capazes de produzir quantidades significantes de citocinas, o que coloca o PLGA como uma partícula coadjuvante do padrão de resposta celular (Jones, 2008; dos Santos et al., 2011).

Os eicosanoides regulam a resposta imune inata por apresentarem propriedades imunomoduladoras, destacando-se a produção de PGE $_{2}$ (Rodriguéz et al., 2014). O presente estudo ainda revelou que mediadores lipídicos não comprometeram de forma significativa a viabilidade celular. O que foi observado foi exatamente o oposto: células viáveis e, até mesmo, aumento no número de células presentes no grupo tratado com a maior molaridade de $\mathrm{PGE}_{2}$. 
A PGE 2 é capaz de se ligar a 4 diferentes tipos de receptores (EP1, EP2, EP3 e EP4, também conhecidos como PTGR1, PTGER2, PTGER3 e PTGER4). O receptor EP1 está acoplado à proteína $\mathrm{G}_{\mathrm{q}}$ e uma vez ativado, aumenta a concentração de cálcio intracelular. Receptores EP2 e EP4 estão acoplados à proteína $\mathrm{G}_{\mathrm{s}}$ e, ao serem ativados, são capazes de aumentar o AMP cíclico (cAMP) intracelular. Por outro lado, o receptor EP3 é acoplado à proteína $G_{i}$ e, ao contrário dos receptores EP2 e EP4, diminui a formação de cAMP. Entretanto, PGs geradas a partir da COX-2 e localizadas na membrana nuclear podem controlar vias nucleares através da interação com receptor ativado da proliferação de peroxissomos (PPAR), o que regula eventos nucleares de crescimento e sobrevivência celulares (Romano e Clària, 2003; Wang e DuBois, 2010). Este evento ocorre em alguns casos quando PGs e seus metabólitos se ligam nestes receptores nucleares, sendo que a $\mathrm{PGE}_{2}$ pode ativar de forma indireta o receptor PPARס (Wang e DuBois, 2010).

É importante salientar que estudos prévios já demonstraram o papel da $\mathrm{PGE}_{2}$ no processo de reparo em tecidos epiteliais através da ativação de vias de sinalização celular, incluindo a vias PI3K/Akt e Wnt, sendo que a $\mathrm{PGE}_{2}$ é capaz de ativar ainda as vias MAPK e JNK através da transativação do receptor do fator de crescimento epidérmico (EGFR) (Nakanishi e Rosenberg, 2013). Apesar de não ser o objetivo do presente estudo avaliar as vias de sinalização geradoras deste padrão de resposta celular, é válido salientar que estes poderiam ser os possíveis mecanismos moleculares que explicariam este comportamento diante da presença de $\mathrm{PGE}_{2}$, de modo especial, quando em maiores quantidades.

Não apenas a modulação da proliferação celular foi afetada pela $\mathrm{PGE}_{2}$, mas também a expressão de importantes genes indutores da mineralização da matriz dentinária, sendo que o mesmo não foi observado ao estimular as células com $\mathrm{LTB}_{4}$.

Sabe-se que a síntese de $\mathrm{LTB}_{4}$ e a sinalização via receptor BLT1 são importantes para ativação da via NF-kB (Serezani et al., 2011), que por sua vez, age com elementos da resposta inflamatória e inibe a ligação de $\beta$-catenina e Runx2 em seus sítios 
correspondentes, o que reduz a expressão das proteínas da matriz óssea (Tarapore et al., 2015).

Como foi possível observar houve tendência ao aumento da expressão gênica de Ibsp no período de 24 horas quando foi realizado tratamento com $\mathrm{PGE}_{2}$ em sua menor molaridade, sendo que, apesar de não haver diferenças estatisticamente significantes do mesmo grupo em relação ao grupo controle, havia tendência à redução da expressão do referido gene após um período de 3 horas. Pode-se dizer, portanto, que a $\mathrm{PGE}_{2}$ foi capaz de restabelecer a expressão gênica de Ibsp após um período de 24 horas presente no meio. Há indícios, portanto, de que a $\mathrm{PGE}_{2}$, quando presente em menor molaridade, tende a regular precocemente a expressão gênica de Ibsp em células indiferenciadas da polpa, destacandose as primeiras 24 horas. Em períodos mais precoces, porém, esta regulação não é observada de maneira diferencial. $A \mathrm{PGE}_{2}$ já mostrou efeito anabólico na proliferação e diferenciação de osteoblastos e induziu a transcrição de BSP (Samoto et al., 2003).

Fatores de crescimento, como a BMP-2, além de moléculas bioativas advindas da matriz dentinária, são importantes moléculas sinalizadoras de células-tronco da polpa dental, estimulando-as a se diferenciarem em células odontoblast-like (Lin e Rosenberg, 2011). Portanto, a avaliação da expressão do gene codificador da proteína Bmp-2 se fez necessária.

O gene $B M P 2$ é essencial para o controle da mineralização da matriz dentinária, e está correlacionado à diferenciação de células da polpa dental. É importante salientar que este gene é visto como sendo eficaz para melhoria do potencial de diferenciação celular (Zhang et al., 2014).

No presente estudo, foi possível observar que a expressão gênica de $B m p 2$ foi mais expressiva quando as células foram tratadas com $\mathrm{PGE}_{2}$ em sua maior molaridade. Estes resultados mostram que este mediador lipídico está envolvido na indução da expressão gênica de $B m p 2$ nos períodos mais iniciais do processo inflamatório, de modo a induzir a diferenciação de células mesenquimais da polpa. 
A literatura revela que a $\mathrm{PGE}_{2}$ foi capaz de induzir a produção de BMP-2 em cultura de células-tronco extraídas de tendão, e consequentemente promover a diferenciação em células da linhagem osteoblástica (Zhang e Wang, 2012). Por outro lado, o LTB $_{4}$ reconhecidamente favorece o processo de reabsorção em tecido ósseo, pois recruta células clásticas e inibe o processo de diferenciação de blastos, mesmo em presença de estímulo com BMP-2 (Traianedes et al., 1998).

Além da expressão de Ibsp e Bmp2, o fator transcricional Runx2 também teve a expressão gênica estimulada pela $\mathrm{PGE}_{2}$ nas 6 primeiras horas de estimulação. 0 Runx2 é o principal gene que controla o processo de diferenciação de odontoblastos e é expresso em células odontoblast-like e em células-tronco da polpa dental na região de deposição de dentina reparadora (Daltoé, 2015), o que o torna o fator transcricional promotor da diferenciação de células-tronco pulpares, para que assim sejam capazes de formar dentina reparadora (Han et al., 2014). De acordo com os resultados obtidos, é possível observar que a $\mathrm{PGE}_{2}$ foi o mediador que teve maior destaque quando foi realizada avaliação da expressão gênica nos diferentes períodos.

A literatura relata que este mediador tem sua produção aumentada em casos de inflamação pulpar experimentalmente induzida (Okiji et al., 1987). Como foi possível observar nos resultados apresentados, a estimulação com o medidor sob a forma de microesferas de molaridade de $0,1 \mu \mathrm{M}$ foi capaz de aumentar a expressão gênica de $R u n \times 2$ nas seis primeiras horas de estimulação. Este dado se revela um grande achado, pois durante o processo inflamatório a $\mathrm{PGE}_{2}$ tem sua produção aumentada por meio de citocinas pró-inflamatórias (IFN- $\gamma$ e TNF-a) (Yu et al., 2014) produzidas durante a resposta imune, o que revela que este mediador está presente no meio inflamatório logo nas primeiras horas. O presente estudo, portanto, revela participação deste mediador lipídico na expressão de Runx2 logo nas primeiras horas de estimulação. Isso sugere que a $\mathrm{PGE}_{2}$ seja um mediador indutor precoce da resposta mineralizadora, pois ao aumentar a expressão de Runx2 tende a 
favorecer a deposição de matriz mineralizadora, haja visto que se trata de um fator transcricional importante na regulação da diferenciação de células-tronco e formação do órgão dental (Wen et al., 2010). A PGE 2 , na realidade, já revelou um papel dual ao participar tanto da reabsorção quanto formação deste tecido ósseo (Yoshida et al., 2002). Similarmente ao que observamos em células indiferenciadas da polpa dental, células do ligamento periodontal humano cultivadas em meio osteogênico e estimuladas com $\mathrm{PGE}_{2}$ em diferentes molaridades tiveram aumento na expressão de $R U N X 2$, o que demonstra que a $\mathrm{PGE}_{2}$ é capaz de modular a expressão deste gene envolvido na regulação osteogênica (Manokawinchoke et al., 2014).

O presente estudo mostrou que os mediadores lipídicos avaliados podem ser importantes para a resposta do complexo dentino-pulpar frente a estímulos inflamatórios. Desta forma, foi possível compreender melhor o papel dos mediadores lipídicos na resposta pulpar frente a eventos inflamatórios, de maneira que foi possível compreender que especialmente a $\mathrm{PGE}_{2}$ é um medidor que desempenha um papel importante sobre o perfil gênico de células indiferenciadas da polpa dental, estimulando-as a expressar genes codificadores da mineralização da matriz dentinária, sugerindo que este medidor apresenta uma importante participação no processo de diferenciação de células da polpa dental, e não apenas em sua multiplicação como foi possível constatar neste estudo.

No entanto, embora tenha se desvendado tais achados, estudos adicionais se fazem necessários para compreender de maneira mais efetiva as vias celulares e moleculares envolvidas no perfil gênico aqui observado, bem como compreender quais mecanismos são ativados pelos mediadores lipídicos que geram a multiplicação de células da polpa dentária em eventos inflamatórios, afim de que se esclareça qual de fato é o papel destes medidores no padrão de resposta celular. 
Conclusãa 

CONCLUSÃO

De acordo com os resultados obtidos neste estudo, pode-se concluir que:

- A $\mathrm{PGE}_{2}$, um mediador do processo inflamatório, encapsulada em microesferas foi capaz de induzir a proliferação de células indiferenciadas da polpa de linhagem de camundongos (OD-21), ao passo que o $\mathrm{LTB}_{4}$ se revelou um mediador não indutor deste processo.

- $A P G_{2}$ encapsulada em microesferas foi capaz de modificar o padrão de expressão gênica de Bmp2 e Runx2 em cultura de células OD-21, sendo que o LTB 4 mostrou um papel inibidor da expressão gênica de Ibsp. 

$R_{\text {eferências }}$ 



\section{REFERÊNCIAS}

1. Back M, Powell WS, Dahlen SE, Drazen JM, Evans JF, Serhan CN, et al. Update on leukotriene, lipoxin and oxoeicosanoid receptors: IUPHAR Review 7. Br J Pharmacol. 2014; 171(15):3551-74.

2. Bleicher F. Odontoblast physiology. Exp Cell Res. 2014;325(2):65-71.

3. Camilleri S, McDonald F. Runx2 and dental development. Eur J Oral Sci. 2006;114(5):361-73.

4. 4. Claria J. Cyclooxygenase-2 biology. Curr Pharm Des. 2003;9(27):2177-90.

5. Charadram N, Austin C, Trimby P, Simonian M, Swain MV, N. H. Structural analysis of reactionary dentin formed in response to polymicrobial invasion. . J Struct Biol 2013. p. 207-22.

6. Chen L, Jacquet R, Lowder E, Landis WJ. Refinement of collagen-mineral interaction: a possible role for osteocalcin in apatite crystal nucleation, growth and development. Bone. 2015;71:7-16.

7. Chen J, Sasaguri K, Sodek J, Aufdemorte TB, Jiang H, Thomas HF. Enamel epithelium expresses bone sialoprotein (BSP). Eur J Oral Sci. 1998;106 Suppl 1:331-6.

8. Chmilewsky F, Jeanneau C, Dejou J, About I. Sources of dentin-pulp regeneration signals and their modulation by the local microenvironment. J Endod. 2014;40(4 Suppl):S19-25.

9. Chogle SM, Goodis HE, Kinaia BM. Pulpal and periradicular response to caries: current management and regenerative options. Dent Clin North Am. 2012;56(3):521-36.

10. Cobourne MT. Familial human hypodontia--is it all in the genes? $\mathrm{Br}$ Dent $\mathrm{J}$. 2007;203(4):203-8.

11. Cooper PR, Holder MJ, Smith AJ. Inflammation and Regeneration in the Dentin-Pulp Complex: A Double-edged Sword. J Endod. 2014;40(4 Suppl):S46-51.

12. Cooper PR, McLachlan JL, Simon S, Graham LW, Smith AJ. Mediators of inflammation and regeneration. Adv Dent Res. 2011;23(3):290-5.

13. Cooper PR, Takahashi Y, Graham LW, Simon S, Imazato S, Smith AJ. Inflammationregeneration interplay in the dentine-pulp complex. J Dent. 2010;38(9):687-97.

14. Couve E, Osorio R, O. S. The Amazing Odontoblast: Activity, Autophagy, and Aging.: ] Dent Res 2013. p. 765-72.

15. Crean D, Godson C. Specialised lipid mediators and their targets. Semin Immunol. 2015.

16. da Cunha JM, da Costa-Neves A, Kerkis I, MC dS. Pluripotent stem cell transcription factors during human odontogenesis. . Cell Tissue Res 2013. p. 435-41. 
17. Daltoé MO. Expressão de marcadores da mineralização na resposta pulpar, in vitro e in vivo, frente à Biodentine ${ }^{\mathrm{TM}}$ e ao Agregado de Trióxido Mineral [dissertação]. Ribeirão Preto: Faculdade de odontologia de Ribeirão Preto da Universidade de São Paulo; 2015.

18. Dennis EA, Norris PC. Eicosanoid storm in infection and inflammation. Nat Rev Immunol. 2015.

19. Dos Santos DF, Bitencourt CS, Gelfuso GM, Pereira PA, de Souza PR, Sorgi CA, et al. Biodegradable microspheres containing leukotriene $B(4)$ and cell-free antigens from Histoplasma capsulatum activate murine bone marrow-derived macrophages. Eur J Pharm Sci. 2011;44(5):580-8.

20. Durand SH, Flacher V, Romeas A, Carrouel F, Colomb E, Vincent C, et al. Lipoteichoic acid increases TLR and functional chemokine expression while reducing dentin formation in in vitro differentiated human odontoblasts. J Immunol. 2006;176(5):2880-7.

21. Farges JC, Alliot-Licht B, Baudouin C, Msika P, Bleicher F, Carrouel F. Odontoblast control of dental pulp inflammation triggered by cariogenic bacteria. Front Physiol. 2013;4:326.

22. Farges JC, Keller JF, Carrouel F, Durand SH, Romeas A, Bleicher F, et al. Odontoblasts in the dental pulp immune response. J Exp Zool B Mol Dev Evol. 2009;312b(5):425-36.

23. Feng XY, Zhao YM, Wang WJ, Ge LH. Msx1 regulates proliferation and differentiation of mouse dental mesenchymal cells in culture. Eur J Oral Sci. 2013;121(5):412-20.

24. Ferreira MR, Dernowsek J, Passos GA, Bombonato-Prado KF. Undifferentiated pulp cells and odontoblast-like cells share genes involved in the process of odontogenesis. Arch Oral Biol. 2015;60(4):593-9.

25. Ford Versypt AN, Pack DW, Braatz RD. Mathematical modeling of drug delivery from autocatalytically degradable PLGA microspheres--a review. J Control Release. 2013;165(1):29-37.

26. Fredenberg $S$, Wahlgren $M$, Reslow $M$, Axelsson $A$. The mechanisms of drug release in poly(lactic-co-glycolic acid)-based drug delivery systems--a review. Int J Pharm. 2011;415(1-2):34-52.

27. Funk CD. Prostaglandins and leukotrienes: advances in eicosanoid biology. Science. 2001;294(5548):1871-5.

28. George A, Gui J, Jenkins NA, Gilbert DJ, Copeland NG, Veis A. In situ localization and chromosomal mapping of the AG1 (Dmp1) gene. J Histochem Cytochem. $1994 ; 42(12): 1527-31$.

29. Gilroy DW. Eicosanoids and the endogenous control of acute inflammatory resolution. Int J Biochem Cell Biol. 2010;42(4):524-8.

30. Guijas C, Rodriguez JP, Rubio JM, Balboa MA, Balsinde J. Phospholipase A2 regulation of lipid droplet formation. Biochim Biophys Acta. 2014;1841(12):1661-71. 
31. Haeggstrom JZ, Rinaldo-Matthis A, Wheelock CE, Wetterholm A. Advances in eicosanoid research, novel therapeutic implications. Biochem Biophys Res Commun. 2010;396(1):135-9.

32. Hammond VJ, O'Donnell VB. Esterified eicosanoids: generation, characterization and function. Biochim Biophys Acta. 2012;1818(10):2403-12.

33. Han N, Zheng $Y$, Li R, Li X, Zhou M, Niu Y, et al. beta-catenin enhances odontoblastic differentiation of dental pulp cells through activation of Runx2. PLoS One. 2014;9(2):e88890.

34. Harizi $\mathrm{H}$, Corcuff JB, Gualde N. Arachidonic-acid-derived eicosanoids: roles in biology and immunopathology. Trends Mol Med. 2008;14(10):461-9.

35. He G, Dahl T, Veis A, George A. Nucleation of apatite crystals in vitro by self-assembled dentin matrix protein 1. Nat Mater. 2003;2(8):552-8.

36. Horst OV, Tompkins KA, Coats SR, Braham PH, Darveau RP, Dale BA. TGF-beta1 Inhibits TLR-mediated odontoblast responses to oral bacteria. J Dent Res. 2009;88(4):333-8.

37. Hoylaerts MF, Van Kerckhoven S, Kiffer-Moreira T, Sheen C, Narisawa S, Millan JL. Functional significance of calcium binding to tissue-nonspecific alkaline phosphatase. PLoS One. 2015;10(3):e0119874.

38. Jones KS. Biomaterials as vaccine adjuvants. Biotechnol Prog. 2008;24(4):807-14.

39. Kawahara K, Hohjoh H, Inazumi T, Tsuchiya S, Sugimoto Y. Prostaglandin E-induced inflammation: Relevance of prostaglandin $\mathrm{E}$ receptors. Biochim Biophys Acta. 2015;1851(4):414-21.

40. Keller JF, Carrouel F, Colomb E, Durand SH, Baudouin C, Msika P, et al. Toll-like receptor 2 activation by lipoteichoic acid induces differential production of pro-inflammatory cytokines in human odontoblasts, dental pulp fibroblasts and immature dendritic cells. Immunobiology. 2010;215(1):53-9.

41. Kim $\mathrm{TH}$, Bae $\mathrm{CH}$, Lee $\mathrm{JC}$, Kim JE, Yang $\mathrm{X}$, de Crombrugghe $\mathrm{B}$, et al. Osterix regulates tooth root formation in a site-specific manner. J Dent Res. 2015;94(3):430-8.

42. Kuzynski M, Goss M, Bottini M, Yadav MC, Mobley C, Winters T, et al. Dual role of the Trps1 transcription factor in dentin mineralization. J Biol Chem. 2014;289(40):27481-93.

43. Larmas MA, Sandor GK. Solid nomenclature: the bedrock of science. Similarities and dissimilarities in phenomena and cells of tooth and bone ontogeny. Anat Rec (Hoboken). 2013;296(4):564-7.

44. Lezot F, Thomas B, Hotton D, Forest N, Orestes-Cardoso S, Robert B, et al. Biomineralization, life-time of odontogenic cells and differential expression of the two homeobox genes MSX-1 and DLX-2 in transgenic mice. J Bone Miner Res. 2000;15(3):430-41.

45. Legler DF, Bruckner M, Uetz-von Allmen E, Krause P. Prostaglandin E2 at new glance: novel insights in functional diversity offer therapeutic chances. Int J Biochem Cell Biol. 2010;42(2):198-201. 
46. Li Z, Jiang CM, An S, Cheng $Q$, Huang $Y F$, Wang $Y T$, et al. Immunomodulatory properties of dental tissue-derived mesenchymal stem cells. Oral Dis. 2014;20(1):25-34.

47. Liu Y, Gao Y, Zhan X, Cui L, Xu S, Ma D, et al. TLR4 activation by lipopolysaccharide and Streptococcus mutans induces differential regulation of proliferation and migration in human dental pulp stem cells. J Endod. 2014;40(9):1375-81.

48. Lin LM, Rosenberg PA. Repair and regeneration in endodontics. Int Endod J. 2011;44(10):889-906.

49. Lombardi G, Perego S, Luzi L, Banfi G. A four-season molecule: osteocalcin. Updates in its physiological roles. Endocrine. 2015;48(2):394-404.

50. Manokawinchoke J, Pimkhaokhum A, Everts V, Pavasant P. Prostaglandin E2 inhibits invitro mineral deposition by human periodontal ligament cells via modulating the expression of TWIST1 and RUNX2. J Periodontal Res. 2014;49(6):777-84.

51. Mathieu S, Jeanneau C, Sheibat-Othman N, Kalaji N, Fessi H, About I. Usefulness of controlled release of growth factors in investigating the early events of dentin-pulp regeneration. J Endod. 2013;39(2):228-35.

52. Mikos AG, Lyman MD, Freed LE, Langer R. Wetting of poly(L-lactic acid) and poly(DLlactic-co-glycolic acid) foams for tissue culture. Biomaterials. 1994;15(1):55-8.

53. Millan JL. The role of phosphatases in the initiation of skeletal mineralization. Calcif Tissue Int. 2013;93(4):299-306.

54. Mosmann T. Rapid colorimetric assay for cellular growth and survival: application to proliferation and cytotoxicity assays. J Immunol Methods. 1983;65(1-2):55-63.

55. Nicolete R, Lima Kde M, Junior JM, Baruffi MD, de Medeiros AI, Bentley MV, et al. In vitro and in vivo activities of leukotriene B4-loaded biodegradable microspheres. Prostaglandins Other Lipid Mediat. 2007;83(1-2):121-9.

56. Nicolete R, Lima Kde M, Junior JM, Jose PJ, Sanz MJ, Faccioli LH. Prostaglandin E(2)loaded microspheres as strategy to inhibit phagocytosis and modulate inflammatory mediators release. Eur J Pharm Biopharm. 2008;70(3):784-90.

57. Nicolete R, Rius C, Piqueras L, Jose PJ, Sorgi CA, Soares EG, et al. Leukotriene B4loaded microspheres: a new therapeutic strategy to modulate cell activation. BMC Immunol. 2008;9:36.

58. Okiji T, Morita I, Kobayashi C, Sunada I, Murota S. Arachidonic-acid metabolism in normal and experimentally-inflamed rat dental pulp. Arch Oral Biol. 1987;32(10):723-7.

59. Okiji T, Morita I, Suda H, Murota S. Pathophysiological roles of arachidonic acid metabolites in rat dental pulp. Proc Finn Dent Soc. 1992;88 Suppl 1:433-8.

60. Paakkonen V, Rusanen P, Hagstrom J, Tjaderhane L. Mature human odontoblasts express virus-recognizing toll-like receptors. Int Endod J. 2014;47(10):934-41. 
61. Papagerakis P, Berdal A, Mesbah M, Peuchmaur M, Malaval L, Nydegger J, et al. Investigation of osteocalcin, osteonectin, and dentin sialophosphoprotein in developing human teeth. Bone. 2002;30(2):377-85.

62. Prasad M, Butler WT, Qin C. Dentin sialophosphoprotein in biomineralization. Connect Tissue Res. 2010;51(5):404-17.

63. Pereira PA, da Silva Bitencourt C, Dos Santos DF, Nicolete R, Gelfuso GM, Faccioli LH. Prostaglandin D-loaded microspheres effectively activate macrophage effector functions. Eur J Pharm Sci. 2015.

64. Powell WS, Rokach J. Biosynthesis, biological effects, and receptors of hydroxyeicosatetraenoic acids (HETEs) and oxoeicosatetraenoic acids (oxo-ETEs) derived from arachidonic acid. Biochim Biophys Acta. 2015;1851(4):340-55.

65. Qin C, D'Souza R, Feng JQ. Dentin matrix protein 1 (DMP1): new and important roles for biomineralization and phosphate homeostasis. J Dent Res. 2007;86(12):1134-41.

66. Radmark O, Werz O, Steinhilber D, Samuelsson B. 5-Lipoxygenase, a key enzyme for leukotriene biosynthesis in health and disease. Biochim Biophys Acta. 2015;1851(4):3319.

67. Rodriguez M, Domingo E, Municio C, Alvarez Y, Hugo E, Fernandez N, et al. Polarization of the innate immune response by prostaglandin E2: a puzzle of receptors and signals. Mol Pharmacol. 2014;85(1):187-97.

68. Romano M, Claria J. Cyclooxygenase-2 and 5-lipoxygenase converging functions on cell proliferation and tumor angiogenesis: implications for cancer therapy. Faseb $j$. 2003;17(14):1986-95.

69. Samoto H, Shimizu E, Matsuda-Honjyo Y, Saito R, Nakao S, Yamazaki M, et al. Prostaglandin E2 stimulates bone sialoprotein (BSP) expression through CAMP and fibroblast growth factor 2 response elements in the proximal promoter of the rat BSP gene. J Biol Chem. 2003;278(31):28659-67.

70. Santos FRR. Papel da via ciclo-oxigenase na inflamação e reabsorção óssea periapical induzidas pelo lipopolissacarídeo bacteriano [tese]. Ribeirão Preto: Faculdade de Odontologia de Ribeirão Preto da Universidade de São Paulo; 2015.

71. Serezani $\mathrm{CH}$, Lewis C, Jancar S, Peters-Golden M. Leukotriene B4 amplifies NF-kappaB activation in mouse macrophages by reducing SOCS1 inhibition of MyD88 expression. J Clin Invest. 2011;121(2):671-82.

72. Smith $A J$, Lesot $H$. Induction and regulation of crown dentinogenesis: embryonic events as a template for dental tissue repair? Crit Rev Oral Biol Med. 2001;12(5):425-37.

73. Staines KA, MacRae VE, Farquharson C. The importance of the SIBLING family of proteins on skeletal mineralisation and bone remodelling. J Endocrinol. 2012;214(3):241-55.

74. Staquet MJ, Carrouel F, Keller JF, Baudouin C, Msika P, Bleicher F, et al. Patternrecognition receptors in pulp defense. Adv Dent Res. 2011;23(3):296-301. 
75. Suzuki S, Haruyama N, Nishimura F, Kulkarni AB. Dentin sialophosphoprotein and dentin matrix protein-1: Two highly phosphorylated proteins in mineralized tissues. Arch Oral Biol. 2012;57(9):1165-75.

76. Suzuki S, Sreenath T, Haruyama N, Honeycutt C, Terse A, Cho A, et al. Dentin sialoprotein and dentin phosphoprotein have distinct roles in dentin mineralization. Matrix Biol. 2009;28(4):221-9.

77. Takai $H$, Matsumura $H$, Matsui S, Kim KM, Mezawa M, Nakayama $Y$, et al. Unliganded estrogen receptor alpha stimulates bone sialoprotein gene expression. Gene. 2014;539(1):50-7.

78. Tarapore RS, Lim J, Tian C, Pacios S, Xiao W, Reid D, et al. NF-kappaB Has a Direct Role in Inhibiting Bmp- and Wnt-Induced Matrix Protein Expression. J Bone Miner Res. 2015.

79. Tecles O, Laurent P, Zygouritsas S, Burger AS, Camps J, Dejou J, et al. Activation of human dental pulp progenitor/stem cells in response to odontoblast injury. Arch Oral Biol. 2005;50(2):103-8.

80. Thesleff I. Epithelial-mesenchymal signalling regulating tooth morphogenesis. J Cell Sci. 2003;116(Pt 9):1647-8.

81. Traianedes K, Dallas MR, Garrett IR, Mundy GR, Bonewald LF. 5-Lipoxygenase metabolites inhibit bone formation in vitro. Endocrinology. 1998;139(7):3178-84.

82. Tsuchiya S, Simmer JP, Hu JC, Richardson AS, Yamakoshi F, Yamakoshi Y. Astacin proteases cleave dentin sialophosphoprotein (Dspp) to generate dentin phosphoprotein (Dpp). J Bone Miner Res. 2011;26(1):220-8.

83. Uozumi N, Kume K, Nagase T, Nakatani N, Ishii S, Tashiro F, et al. Role of cytosolic phospholipase A2 in allergic response and parturition. Nature. 1997;390(6660):618-22.

84. Veerayutthwilai O, Byers MR, Pham $T$, Darveau RP, Dale BA. Differential regulation of immune responses by odontoblasts. Oral Microbiol Immunol. 2007;22(1):5-13.

85. von Marschall Z, Fisher LW. Dentin sialophosphoprotein (DSPP) is cleaved into its two natural dentin matrix products by three isoforms of bone morphogenetic protein-1 (BMP1). Matrix Biol. 2010;29(4):295-303.

86. Wang D, Dubois RN. Eicosanoids and cancer. Nat Rev Cancer. 2010;10(3):181-93.

87. 87. Wen J, Tao R, Ni L, Duan Q, Lu Q. Immunolocalization and expression of Runx2 in tertiary dentinogenesis. Hybridoma (Larchmt). 2010;29(3):195-9.

88. Woltgens JH, Lyaruu DM, Bronckers AL, Bervoets $\mathrm{TJ}$, Van Duin M. Biomineralization during early stages of the developing tooth in vitro with special reference to secretory stage of amelogenesis. Int J Dev Biol. 1995;39(1):203-12.

89. Yalvac ME, Ramazanoglu M, Rizvanov AA, Sahin F, Bayrak OF, Salli U, et al. Isolation and characterization of stem cells derived from human third molar tooth germs of young adults: implications in neo-vascularization, osteo-, adipo- and neurogenesis. Pharmacogenomics J. 2010;10(2):105-13. 
90. Yang F, Xu N, Li D, Guan L, He Y, Zhang Y, et al. A feedback loop between RUNX2 and the E3 ligase SMURF1 in regulation of differentiation of human dental pulp stem cells. J Endod. 2014;40(10):1579-86.

91. Yang J, Ye L, Hui TQ, Yang DM, Huang DM, Zhou XD, et al. Bone morphogenetic protein 2-induced human dental pulp cell differentiation involves p38 mitogen-activated protein kinase-activated canonical WNT pathway. Int J Oral Sci. 2015;7(2):95-102.

92. Yamashiro T, Tummers M, Thesleff I. Expression of bone morphogenetic proteins and Msx genes during root formation. J Dent Res. 2003;82(3):172-6.

93. Yoshida K, Oida H, Kobayashi T, Maruyama T, Tanaka M, Katayama T, et al. Stimulation of bone formation and prevention of bone loss by prostaglandin E EP4 receptor activation. Proc Natl Acad Sci U S A. 2002;99(7):4580-5.

94. Yu KR, Lee JY, Kim HS, Hong IS, Choi SW, Seo Y, et al. A p38 MAPK-mediated alteration of COX-2/PGE2 regulates immunomodulatory properties in human mesenchymal stem cell aging. PLoS One. 2014;9(8):e102426.

95. Zhang J, Wang JH. BMP-2 mediates PGE(2) -induced reduction of proliferation and osteogenic differentiation of human tendon stem cells. J Orthop Res. 2012;30(1):47-52.

96. 96. Zhang W, Zhang X, Ling J, Liu W, Ma J, Zheng J. Proliferation and odontogenic differentiation of BMP2 genetransfected stem cells from human tooth apical papilla: an in vitro study. Int J Mol Med. 2014;34(4):1004-12.

97. Zhu Q, Gibson MP, Liu Q, Liu Y, Lu Y, Wang X, et al. Proteolytic processing of dentin sialophosphoprotein (DSPP) is essential to dentinogenesis. J Biol Chem. 2012;287(36):30426-35. 